Review Article

\title{
Engineering a Biocompatible Scaffold with Either Micrometre or Nanometre Scale Surface Topography for Promoting Protein Adsorption and Cellular Response
}

\author{
Xuan Le, ${ }^{1}$ Gérrard Eddy Jai Poinern, ${ }^{1}$ Nurshahidah Ali, ${ }^{1}$ \\ Cassandra M. Berry, ${ }^{2}$ and Derek Fawcett ${ }^{1}$ \\ ${ }^{1}$ Murdoch Applied Nanotechnology Research Group, Department of Physics, Energy Studies and Nanotechnology, \\ School of Engineering and Energy, Murdoch University, Murdoch, WA 6150, Australia \\ ${ }^{2}$ Division of Health Sciences, School of Veterinary and Biomedical Sciences, Murdoch University, \\ Murdoch, WA 6150, Australia
}

Correspondence should be addressed to Gérrard Eddy Jai Poinern; g.poinern@murdoch.edu.au

Received 12 June 2012; Revised 2 November 2012; Accepted 13 December 2012

Academic Editor: Rosalind Labow

Copyright (C) 2013 Xuan Le et al. This is an open access article distributed under the Creative Commons Attribution License, which permits unrestricted use, distribution, and reproduction in any medium, provided the original work is properly cited.

\begin{abstract}
Surface topographical features on biomaterials, both at the submicrometre and nanometre scales, are known to influence the physicochemical interactions between biological processes involving proteins and cells. The nanometre-structured surface features tend to resemble the extracellular matrix, the natural environment in which cells live, communicate, and work together. It is believed that by engineering a well-defined nanometre scale surface topography, it should be possible to induce appropriate surface signals that can be used to manipulate cell function in a similar manner to the extracellular matrix. Therefore, there is a need to investigate, understand, and ultimately have the ability to produce tailor-made nanometre scale surface topographies with suitable surface chemistry to promote favourable biological interactions similar to those of the extracellular matrix. Recent advances in nanoscience and nanotechnology have produced many new nanomaterials and numerous manufacturing techniques that have the potential to significantly improve several fields such as biological sensing, cell culture technology, surgical implants, and medical devices. For these fields to progress, there is a definite need to develop a detailed understanding of the interaction between biological systems and fabricated surface structures at both the micrometre and nanometre scales.
\end{abstract}

\section{Introduction}

The last two decades have seen a tremendous level of fundamental research and development into nanotechnology. Recent developments in material science, engineering, biotechnology, and biomedical fields have clearly demonstrated the many potential applications of nanotechnology $[1$, 2]. The basis of this intense nanotechnology-based research is derived from the fact that nanoscale matter can have significantly different properties than its bulk counterpart $[3,4]$. The discovery and investigation of these unknown properties, using new advanced characterization techniques, have the potential to deliver detailed information that can be used to develop many new nanotechnology-based applications. These new characterization techniques have come about from the development of the atomic force microscope (AFM) and the scanning tunnelling microscope (STM) in the 1980s [5]. Both these techniques have given researchers the unprecedented ability to explore and chart the properties of these newly created nanomaterials. These newly discovered nanomaterials have the potential to revolutionize many current pharmaceutical and biomedical applications; and along the way they have the potential to generate new superior tools to assist in current therapies and provide the foundations for new avenues of biomedical intervention in the near future.

Currently, there are a number of processing techniques capable of producing nanomaterials, but recent studies have focused on refining these processes to produce new nanoscale materials. A few processes that are currently being investigated and refined to produce high-quality nanomaterials are 
chemical vapour deposition to produce carbon nanotubes and carbon nanostructures [6,7], ultrasound techniques to produce nanohydroxyapatite crystals for biomedical applications $[8,9]$ and the wet sol-gel synthesis method for creating iron oxide $\left(\mathrm{Fe}_{2} \mathrm{O}_{3}\right)$ nanoparticles $[10,11]$. The most attractive feature of using nanotechnology-based processing techniques is that it gives the manufacturer far greater control over the polydiversity, phase, crystalline structure, topography, morphology, and quality of the nanomaterials produced.

From a biomedical point of view, the cell is the basic unit of a biological system and every organism either consists of cells or is itself a single cell [12]. While cells are generally in the micrometer-size range, their component structures and associated environment are generally in the nanometre to submicrometre range. In fact, the molecular building blocks of life, such as proteins, carbohydrates, nucleic acids, and lipids, are all nanometre scale structures. And from the cellular perspective, the interaction between the cell and nanometre scale structures such as proteins are crucial for controlling a variety of cell functions such as proliferation, migration, and the production of the extracellular matrix (ECM) (Figure 1) [13]. In addition, the physical structure and chemistry of the nanometre scale structure directly influence the behaviour of the cell in contact with the surface of the nanometre scale structure. For example, when a biomaterial comes into contact with the internal cellular environment of the body, proteins spontaneously adsorb onto the surface. This results in the formation of a surfacebound protein layer, which mediates between the biomaterial surface and the cell surface receptors during subsequent cell attachment. How the geometrical and chemical properties of a biomaterial surface influence the adhesive attachment of the cell to the surface and its subsequent influence on the proliferation of anchorage-dependent cells is still an area of active investigation. Furthermore, the adsorption of proteins to the surface of nanometre scale structures is highly dependent on the nature of the surface; for example, surface charge, surface chemistry [14], wettability [15], surface density of cell-binding ligands [16], and nanotopography [17] all play an important role in determining the cell-substrate interaction. In particular, cells are highly sensitive to the local nanotopographic landscape of the ECM and the substrate. For example, Yao et al. have shown that the nanometre topography of bioimplant materials such as Titanium (Ti) and its alloys $\left(\mathrm{Ti}_{6} \mathrm{Al}_{4} \mathrm{~V}\right.$ and anodized $\mathrm{Ti}$ ) can enhance the adhesion between osteoblast cells and the surface of the underlying substrate $[18,19]$. Similar studies by Webster et al. have also revealed an enhanced attachment function between osteoblast cells and nanoceramic surfaces [20].

\section{Tissue Engineering}

The field of tissue engineering came into existence during the mid-1980s to address the high demands for regenerated tissues in clinical applications. Its creation resulted from the convergence of several scientific, technological fields, biotechnology, and medicine. Tissue engineering is still an

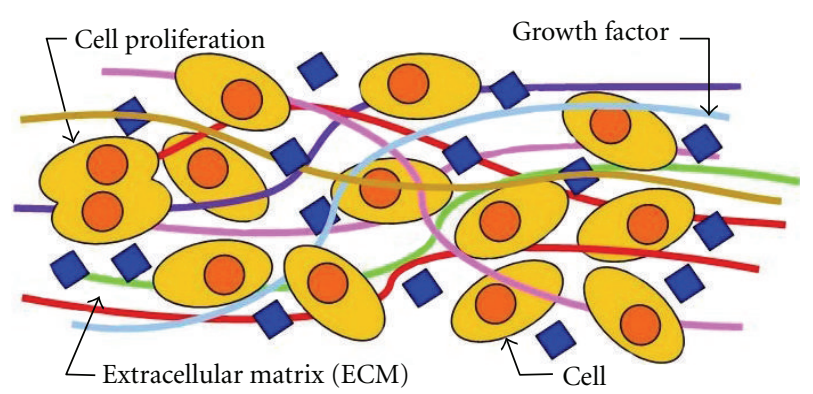

FIGURE 1: Schematic of the cellular environment.

evolving field whose primary function is to recreate the appropriate signals to cells that promote biological processes, which can then create new and/or repair damaged tissues by rational design. According to Langer and Vacanti, tissue engineering is a highly interdisciplinary field that combines engineering principles, biological sciences, and medicine toward the development of biological substitutes to restore, replace, maintain, or enhance tissue and organ function [21, 22].

Development over the past few decades in this field has produced engineered implantable human tissues such as bone, cartilage, and skin $[23,24]$. Currently, there are clinical trials underway that are investigating the feasibility of using tissue engineering techniques to produce a human bladder and blood vessels [23]. The research to date has clearly demonstrated that a major function of tissue engineering is to create an environment that can promote productive and efficient cellular activity; however, this environment is influenced by a number of tissue-dependent factors. A recent study by Yang et al. has revealed that tissue engineering is composed of four key factors: (1) cells, (2) scaffolds, (3) bioreactors, and (4) signals [25]. To obtain the most beneficial and effective outcome, an exhaustive examination of these key factors is needed to achieve the most appropriate contribution from each step for the particular tissue being addressed. This equates to determining, developing, and instituting the most promising environment that can support optimal survival conditions for the tissue undergoing regeneration. The first step in any tissue engineering process involves the harvesting of appropriate cells from donor sites and then introducing these seed cells into a suitable scaffold structure contained within a suitable growing medium. The biocompatible scaffold structure provides a 3-dimensional (3D) environment which promotes cell attachment and proliferation [26]. Apart from being 3D, the scaffold should be made from a biocompatible degradable nontoxic material and should be highly porous to permit the diffusion of nutrients, oxygen, and waste products [27]. This is where nanotechnology can have a significant role to play, since nanotechnology permits the creation of a specialized scaffold structure that can be specifically designed for the particular cell or tissue type. Furthermore, the scaffold can be enhanced to provide the maximum environmental conditions for optimal cellular growth.

Many studies have shown that cells in general tend to behave more naturally when they are cultivated in a $3 \mathrm{D}$ 
scaffold environment [28]. This has resulted in the design of 3D scaffolds that incorporate tissue-specific topographical and environmental enhancements. These enhancements are capable of creating an appropriate microenvironment that can support, regulate, and assist cell function. For example, cells that were cultivated on scaffolds containing $10-100-\mu \mathrm{m}$-sized ridges and grooves promoted elongated cell growth that was orientated in the direction of the surface feature [29]. Cells in their natural tissue environment are generally surrounded by the ECM, a structure composed of many interwoven fibrous molecules, which forms the architectural structure capable of supporting and directing cell behaviour via cell-ECM interactions. The natural scaffold structure of the ECM is a complex formation of architectural features such as fibres, pores, and ridges that vary in size, which are capable of providing physical signs that can directly affect cell behaviour [30-33]. The ECM is composed of proteins such as fibrous collagen, fibronectin, proteoglycans, laminin fibres, and hyaluronic acid, which gives the natural scaffold its chemical, mechanical, and topographical signals that are needed to influence cell behaviour [34]. Therefore, it is important when developing 3D scaffolds that the scaffold biomimics features of biological tissues either compositionally or structurally so that the scaffold can replicate the regeneration process in a similar way to nature. For example, the scaffold topography can directly influence growth parameters responsible for cell adhesion, apoptosis, differentiation, genetic expression, migration, morphology, orientation, and proliferation $[35,36]$.

In particular, topological features provide contact guidance for the cell, which influences the cytoskeletal arrangement and adhesion of the cell [37]. Historically, Harrison was the first to observe the interaction between a substrate's topography and cellular tissue when investigating spider silk fibres in 1911 [38]. The nerve cells tended to grow in a bipolar shape orientated along the fibres. The term "contact guidance" was later coined by Weiss in 1945 to describe the effect of the fibres on cell orientation and proliferation $[39,40]$. Recently, Allmeling et al. have investigated the column growth of Schwann cells along the length of spider silk fibres for a possible nerve conduit and found that the structure promoted successful cell adhesion and migration [41]. Studies of other cultivated cells on different planar scaffold materials, containing arrays of micrometer-sized protrusions have promoted cell attachment and reduced cell proliferation [42]. These studies have clearly demonstrated that controlling the surface features of the scaffold in a specific way can directly influence cellular adhesion, protein absorption, proliferation, and morphology. In addition, cells also have the ability to transform their microenvironments on the scaffold structure by changing the ECM it produces. This can be done by synthesizing or degrading the ECM, secreting cytokines, and communicating with other cells and matrix on the scaffold by molecular and physical signals [43]. It is clear that the interaction between the individual cells, the ECM, and the nanotopographic surface features of the scaffold is a dynamic process and is crucial to fully understand the cellular response as a whole in developing suitable biomaterials for tissue engineering.

\section{Construction of a Tissue Scaffold}

The scaffold architecture used in tissue engineering has three distinct size ranges. The first is the superstructure; this size range essentially covers the overall shape and dimensions of the scaffold. The second is the microstructure, which refers to the scaffold surface features at the cellular level and final size range is the nanostructure, which refers to the subcellular features of the scaffold surface [35]. Generally, biomaterials used in tissue engineering applications such as tissue repair and regeneration have generally favoured bioinert materials for permanent bioimplants such as hip and knee replacements [44]. In the case of scaffolding materials, both natural and inorganic, including metal oxides, have been investigated [45]. The selection of the material used to manufacture the scaffold is an important factor in its successful application. A wide variety of natural biodegradable materials have been extensively studied for potential use in tissue engineering since the body's natural pathways can effectively deal with the by-products resulting from their breakdown. Natural polymers such as polysaccharides [46-50], chitosan [5156], hyaluronic-based derivatives [57-60], and protein-based materials such as fibrin gel [61,62] and collagen [63-66] have all shown some positive outcomes during investigative trials. However, on the whole, these polymeric materials lack sufficient mechanical strength to effectively support tissue growth in the body environment. On the other hand, inorganic or synthetic biodegradable polymers have been fabricated under controlled conditions to produce a variety of scaffold structures with selectable, predictable mechanical, and physical properties.

Biopolymer materials are composed of simple, highpurity constituent monomers. An advantage of biopolymers is that they have a controllable degradation rate within the body's environment and their reactions to the body fluids during degradation produce low toxicity by-products that can easily be handled by the bodily excretory functions. Examples of these bulk biodegradable polymers include poly-(lactic acid) (PLA) [67-72], poly(1-lactic acid) (PLLA) [65, 7375] poly(lactic-co-glycolic acid) (PLGA) [76-79], polycaprolactone (PCL) [74, 80-82], and poly(glycolic acid) (PGA) [83-86]. These are generally poly- $\alpha$-hydroxy esters that deesterify in the body environment as the polymer slowly degrades to produce simple metabolites [87]. An example of biopolymers currently in use is the biodegradable sutures composed of PLA and PLG that are employed in medical procedures. Because polymers are such good biocompatible materials, they have also been extensively investigated for the controlled delivery of drugs to specific organs within the body [88-90]. In general, polymers are strong and can be fabricated into a variety of different shapes and structures, such as, disks, fibres, films, and pellets, as required for the specific application. In addition, they can be produced with microtypographical surface features that can effectively induce physical cues that can enhance cell interaction with the surface of the scaffold.

Another promising material with new and novel properties for biomedical applications is polyhedral oligomeric silsesquioxane (POSS). The material structure consists of 
an inner inorganic framework of silicon and oxygen atoms which form a nanometre size cage. Surrounding the cage is an outer shell of organic groups which can be composed of hydrogen, alkyl, alkene, and arylene. The biomedical applications of POSS arise from the materials biocompatibility, biostability nontoxicity, cytocompatibility, and resistance to degradation [91-93]. It is due to these properties that POSS has been incorporated into wide range of nanostructured copolymers for a number of biomedical applications such as biomedical devices (heart valves, coronary stents) [94, 95], drug delivery [96], and tissue engineering [92].

Inorganic materials such as bioglass, ceramics, and metal oxides have also been investigated for possible use in tissue engineering applications. This research stream stems from the fact that despite the successful application of polymers, there are still some unresolved issues that need to be resolved. The first issue stems from the local inflammatory response of the surrounding tissues to the presence of the polymer material, and the second results from the uneven degradation process of polymer used in the scaffold. In spite of this, polymer scaffolds are superior to both ceramic and metal oxides for soft tissue applications such as skeletal muscle, cardiovascular tissue, and skin substitutes. The advantage of using polymers in soft tissue applications stems from their close chemical and physical similarity to natural cellular tissues [97-99]. Studies using bioactive glass as a scaffold material have revealed that when the glass was seeded with osteoblasts, there was an enhancement of cellular proliferation [100]. Furthermore, metals such as pure tantalum (Ta) have also been successfully used to produce tissue scaffolds for the adhesion, growth, and differentiation of osteoblasts. One innovative technique used to create a Ta scaffold begins with the pyrolysis of polyurethane foam [101]. The foam turns into a low-density carbonaceous skeleton composed of a repeating dodecahedron structure that produces an interconnecting array of pores. In the next stage, a chemical vapour deposition/infiltration technique (CVD/CVI) is used to deposit pure Ta onto the carbon skeleton and produce a porous metal scaffold. The structural integrity of the scaffold increases as the deposition process continues. An advantage of this deposition process results in the formation of a crystallographic growth pattern that orientates the Ta layer to form a microtextured surface, which is similar to cancellous bone $[102,103]$. In addition, by changing the characteristics of the precursor polymer used and the thickness of the Ta layer deposited onto the carbon skeleton it is possible to control the size of the pores produced. For orthopaedic applications, the thickness of the Ta layer ranges from 40 to $60 \mu \mathrm{m}$, while the pore size ranges from 400 to $600 \mu \mathrm{m}$, and the resulting scaffold porosity can vary from $75 \%$ to $80 \%$. The high porosity and large pore size are ideal for deep and extensive vascular tissue penetration, which results in strong tissue attachment strengths [104]. This type of vascular tissue penetration and subsequent growth has also been seen in images of highly porous alumina ceramic foam metals [105]. Furthermore, studies into the growth of osteoblasts on metal oxide surfaces such as nano-porous alumina have also shown a positive response [106, 107].
3.1. Important Parameters Needed for a Successful Scaffold Structure. The operational demands that are placed on a substrate's scaffold structure when implanted into the body environment are numerous, and the scaffold must overcome many challenges to achieve a successful clinical outcome. For example, the biocompatibility of the scaffold material is crucial in preventing any cytotoxicity, immunological reactions, and inflammation responses from the body [108110]. This is particularly important since the presence of any scaffold material within the body environment will initiate an inflammatory response at the scaffold site. As a consequence, a complex biochemical cascade of events takes place in which cells arrive and start producing chemokines, cytokines, and growth factors to initiate the repair of damaged tissue surrounding the scaffold site. The presence of these cells on the surface of the scaffold can initiate a foreign body reaction to biomaterial used to manufacture the scaffold. These cells produce oxygen radicals and enzymes that have the potential to degrade the scaffold which can ultimately lead to the failure of the scaffold [111]. Recent in vitro and in vivo studies by Lamers et al. have revealed that the immunological response to a biomaterial surface could be altered by introducing nanometre sized grooves to a substrate surface [112]. The nanometre patterned surfaces were found to solicit a response from murine macrophages (cell line RAW264.7) which resulted in an altered gene expression and protein secretion after $24 \mathrm{~h}$ in vitro. However, there was no noticeable change in protein secretion during the in vivo study. These studies highlight the importance of using a biomaterial with appropriate surface topography to solicit a favourable immunological outcome, since the macrophages were clearly sensitive to the nanometre scale groove features and may assist in the healing process. The scaffold provides the initial framework for the seeded cells to attach, proliferate, and differentiate. During this process, the initial scaffold mimics the ECM environment, and as new ECM, is being created by the cells, it will provide integrity to the new tissues as the scaffold slowly degrades over time. The surface chemistry of the scaffold material is an important factor during the formation of new ECM, since the scaffold must be chemically compatible with the ECM. Since the ECM is nature's own tissue scaffold and forms the cell environment, it is desirable that any engineered scaffold biomimics the ECM as close as possible. This is because the chemistry and topography of the ECM provides the cues that initiate and modulate cell adhesion, cellular interaction, proliferation, and migration [30, 64, 113-118].

In exploring their surrounding environment, cells receive a variety of complex biochemical and biophysical signals via filopodia at the cell boundaries which spread out over the surface of the ECM [117]. To accomplish a number of biological processes, cell movement, and migration must take place. The cell achieves motion through the action of protrusions from the cell membrane, forming integrin adhesions combined with cellular contractions. The direction of cell motion is guided by environmental stimuli such as biochemical and biophysical signals. In addition, cells also respond to mechanical stimuli in the form of gradients in the mechanical stiffness or rigidity of the substrate-a phenomena known as 
durotaxis that results in cell membrane stretch, compression, and interaction with the surface topography [119-121]. Cells that come in contact with stiff substrates develop strong focal adhesions that securely anchor the cell to the substrate. This is in contrast to soft substrates which induce small, transitory adhesions that are unstable and provide weak anchorage for the cell. In effect, durotaxis creates a bias that influences the direction of cell migration from softer substrate regions towards regions that are characterised by increasing elasticity or stiffness [122]. For instance, multipotent mesenchymal stem cells (MSCs) display lineage-specific differentiation when cultured on substrates that mimic the stiffness of native tissue environments. In the case of MSCs cultured on substrate that mimics the bone environment, the cells become osteogenic. While MSCs exposed to substrates that mimic a myogenic tissue environment become muscle cells $[123,124]$.

In addition, the biomaterial needs to be able to prevent any rapid bulk degradation effects that might result in the formation of voids and defects within the scaffold structure. Another important property of a biomaterial is its ability to be easily sterilized prior to its application without any significant changes to its surface chemistry [64, 125-128]. Also, the biomaterials used in the construction of the scaffold should not be hydrophobic, since the wettability of the material is an important factor that must be carefully considered for successful cellular adhesion and attachment. At the molecular level, it is extremely important that the scaffold contains a network of pores and interconnecting channels to facilitate the diffusion of nutrients, oxygen, metabolites, and waste products. Kim and Coulombe were able to demonstrate that pore size and a high surface area to volume ratio were important parameters that encouraged cell penetration and subsequent growth in the scaffold structure to form cellular associations [129]. In addition, if the scaffold structure is going to be rather large, then the structure should be designed to contain a life-supporting capillary-like network as an integral part of the scaffold. Furthermore, the interactions between the cell micrometre scale topography and nanometre scale topography of the scaffold structure can influence cell attachment and adhesion, proliferation, and migration. A recent investigation by Andersson et al. revealed a link between epithelial cell attachments to surfaces of similar chemistry and that the cell morphology and cytokine production were strongly dependent on the underlying nanometre scale $\mathrm{TiO}_{2}$ deposited surface topography [130].

3.2. Scaffold Manufacturing Techniques. The cells in the human body are micrometre sized objects, with the largest cells being the anterior horn in the spinal cord $(\sim 135 \mu \mathrm{m})$ and the smallest being the granule cells in the cerebellum $(\sim 4 \mu \mathrm{m})$, with a typical cell size between 10 to $20 \mu \mathrm{m}$ [131]. While the topography created by the ECM proteins are generally in the submicrometre to nanometre size range. This size range has been shown to have an influence over cell behaviour at the cellular level [132]. Since cells are responsive to the topography of the ECM, engineered scaffolds and substrates must also display similar surface topographical features that can provide effective signals to influence cellular behaviour. In addition, the size, density, and distribution of the topographical features found on the surface of the ECM are also dependent upon the types of cellular tissues that form the ECM $[32,133]$. Therefore, it is important that the information derived from the specific cell generated ECM topography is translated into an effective fabrication process that replicates these surface features onto tissue culture substrates and scaffolds [134].

There are three main categories used to define the type of topographical features that can be fabricated, the first is ordered, which involves the production of accurate repeatable surface features and the second involves the formation of irregular or unordered features such as surface roughening and fibrils $[35,135]$. Both of these categories attempt to replicate the topographical features of the ordered ECM, the third involves the removal of cells from body tissues and then use the native decellularized tissues as cell culture scaffolds [136].

Biological scaffolds composed of decellularized tissues and organs are capable of providing a natural ECM structure that can be used for a variety of tissue engineering applications [137-139]. The ECM harvested from a number of tissue sources are then used in a number of tissue engineering applications such as blood vessels [140, 141], heart valves $[142,143]$, urinary bladder $[144,145]$, small intestinal submucosa [146, 147], liver [148, 149], skin [150], and lung [151]. If properly prepared, the decellularized tissue scaffold can preserve much of the original ECM structure and bioactive functional molecules, which enables the scaffold to provide important physical and chemical signals needed to support cell functions such as attachment, differentiation, and proliferation. The use of biological derived tissues as scaffold structures has the potential to create an effective environment to induce cellular growth. To date, decellularized ECM scaffolds have been described for a number of organs, with an engineered bioartificial heart being investigated in vivo using an animal model [152].

During the late 1970's and early 1980's with the development of cellular telephones, digital devices and the personnel computer in the electronics industry, it was possible to develop many novel micrometre and later, nanometre scale fabrication techniques to manufacture extremely small and compact equipment. Using these new fabrication techniques in conjunction with the continually developing biomaterials field, many research teams across the world have the potential to fabricate 3D scaffold structures that can effectively biomimic the topographical features of the ECM. Once the specific tissue engineering application has been identified, the required chemical, physical, and mechanical properties can be determined and then a suitable fabrication technique can be selected to manufacture the scaffold structure.

Technologically driven top down micrometre and nanometre scale lithographic fabrication techniques have been used to produce a variety of topographical features such as grooves, gratings, pillars, spheres, pits, and tubes (see Figure 2). These techniques have the ability to control the fabrication of accurate and highly reproducible topographical features over the surface of a variety of substrates. Several lithographic techniques have developed over the years 


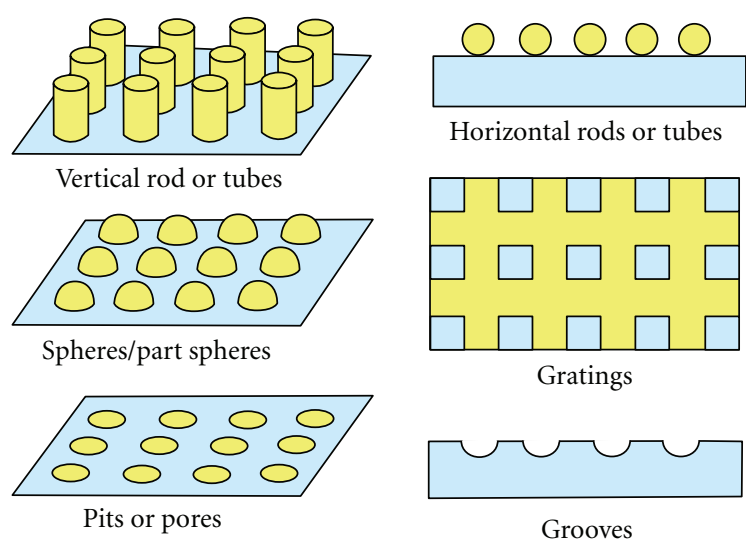

Figure 2: Some typical topographical surface features.

that have enabled researchers to explore a variety of celltopography interactions on materials such as silicon, polymers, and titanium [132]. Electron beam lithography, which was originally developed for producing integrated circuits has been successfully used to produce both micrometre and nanometre scale topographical features on the surface of several biocompatible materials. However, this technique is relatively expensive and time consuming due to substrate exposure time, which limits the production of substrates and scaffolds [153]. Photolithography is a process which selectively removes predetermined material from the surface of a substrate to fabricate micrometre topography. The first use of this technique for cell response studies was made in the early 1980s when a series of micrometre scale grooves were formed in the surface of a silica substrate [154]. Other techniques such as X-ray lithography, laser ablation, nanoimprinting, and microcontact lithography have also been used effectively used to produce topographical features on a variety of materials.

Two recent techniques that may provide improved routes for the fabrication of $3 \mathrm{D}$ cellular scaffolds for a variety of tissue engineering applications are self-folding materials and multiphoton lithography. Micrometre scale fabrication of 3D structures by controlled out of the plane self folding of 2D patterns using a laser direct-write-based technique has the potential to create elaborate and precisely structured substrates that can be used to model in vivo cell behaviour [155]. The Japanese art of paper folding known as origami transforms $2 \mathrm{D}$ patterns into $3 \mathrm{D}$ shapes. A similar approach uses self-folding, a self-assembly process in which planar structures fold up from the 2D substrate when exposed to specific activation stimuli [156]. For example, laser origami uses a laser direct-write technique to produce feature through laser fabrication of the pattern in the substrate, then deposit the active elements on the pattern via laser transfer or cutting and finally the substrate is heated using the laser which results in the cut patterns folding up out of the substrate [156]. The other recent technique is Multiphoton lithography (MPL) which can be used to fabricate 3D tissue scaffold structures. It is a computer controlled fabrication technique in which the morphological features of a biological structure are programmed as stack of $2 \mathrm{D}$ tomographic cross sections.
The cross sections act as input for a sequence of reflective photomasks that are used to direct the replication of the biological structure. The direct-write process, using a laser, translates the programmed data from the cross sections into a protein-based 3D reproduction of the original biological structure [157]. This technique is capable of producing complex 3D structures with well defined architectural features such as size, shape, inter connectivity, branching, geometry, and orientation that have the potential to mimic complex 3D biological structures [157]. Many of these top down techniques tend to be very expensive since they require specialised instrumentation and equipment, complex ultrahigh vacuum systems, and clean room facilities.

On the other hand, the electrospinning process, which was originally developed by the textile industry, has been used for the past 100 years. Refinements of the technique in the last decade have seen it increasingly used in the manufacture of fibre with diameters ranging in size from many microns to tens of nanometres [158]. The fibres produced are used to form a nano-fibrous porous structure that permits cells to enter the scaffold, while allowing the flow of nutrients and waste products from the cells $[159,160]$. Scaffold structures of synthetic polymers such as PLA and PLGA, and natural polymers such as collagen (types I, II, III), chitosan, elastin, fibrin, and silk have been produced using this technique. Agarwal et al. have demonstrated that polymeric materials manufactured using this technique induce a favourable and conducive response from the cells during attachment and subsequent proliferation [66]. The favourable and conducive responses of the scaffold to the cells can be further enhanced by modifying properties such as fibre diameter, porosity, and morphology by simply adjusting the electrospinning conditions. Further enhancement of the electrospun material can also be achieved by modifying the fibres to resemble the ECM at the nanometre scale level. This technique involves coating the polymeric fibres with collagen macromolecules, but this process is still evolving, and there are still many challenges ahead.

The phase separation/emulsification technique has been used to produce scaffold structures using a suitable polymeric material $[161,162]$. This method is based on the principles of phase separation, for example, PLGA is dissolved in methylene chloride and then by adding water produces an emulsion. This mixture is then poured into a mould and freeze-dried, during which both the water and methylene chloride are removed leaving a highly porous scaffold structure [163]. Recent developments in this technique have produced scaffolds with nanometre scale topographical features abrading the surface, which have resulted in an enhanced cell response to this material $[126,164,165]$. Similar investigations carried out by Ma have revealed that nanopolymers produced using this technique have a distinct advantage in terms of the increased surface area and the resulting enhanced 3D connectivity for various cell types used in tissue engineering applications $[88,166]$. Other techniques such as micelle lithography, polymer de-mixing, chemical vapour deposition, chemical etching, and anodization have all been used to produce scaffolds with topographical features capable of soliciting a positive cellular response [35, 167-170]. 


\section{Cell Response and Behaviour to Surface Topography}

4.1. Micrometre Scale Topography. With the advent of tissue engineering in the mid-1980s, various fabrication techniques have been used to produce a variety of cell culture substrates and scaffolds to meet the high demands for regenerated tissues. Since then there has been a considerable amount of research into the interactive relationship between cells and micrometre scale surface topography of substrates and scaffold structures. Many studies have reported the influence of submicrometre to nanometre scale topographical features, which are smaller than the size of the cell, on cell adhesion, migration, proliferation, and morphology. These features have size ranges that are similar to the size and topography of proteins found in the ECM [171-179]. And recently, Dalby et al. showed that the interaction of fibroblast cell filopodia with surface features as small as $10 \mathrm{~nm}$ directly influenced cell adhesion [180]. Being able to create precise topographical features has made it possible for researchers to investigate the interaction between surface topography and cellular behaviour such as contact guidance [181-187]. The most commonly studied topographical feature is the groove, and its dimensions can provide physical signals to orientate the cell. For example, human gingival cells seeded in micrometre scale grooves fabricated in a silica substrate produced cellular growth that was aligned with the grooved topography [154]. Subsequent investigation found that increasing the depth of the groove enhanced cell alignment, while increasing groove width produced less cell alignment [174]. In addition, in a similar study, mesenchymal cells grown on quartz substrates attach to the ridges of the grooves and then spread via bridging the ridges. The cells not only aligned themselves parallel with the grooves, but they also migrated between 3 to 5 times faster than those on smooth level surfaces [188].

The influence of the topographical feature can have a significant effect on the cell and in some cases dominate other substrate signals such as surface chemistry. Neurons cultured on substrates with a number of protein (laminin) tracks, orientated perpendicular to a range of grooves with varying depths revealed that the neurites aligned themselves with the protein cue when the grooves were shallow. However, when the groove depths were greater than $500 \mathrm{~nm}$ the topographical feature became the dominant influence on cell alignment [189]. Furthermore in a similar study, the influential dominance of topography in manipulating and orientating cells was further demonstrated when osteoblasts were aligned by surface grooves rather than chemical cues [190]. Not all cell lines orientate themselves with the groove or ridge, this behaviour is dependent on the topography and the cell type. For example, embryonic rat spinal cord and hippocampus neurons cultured on grooved patterned quartz substrates revealed that neurite spreading was governed by dimensions of the groove and the cell type. The neurites of the spinal neurons tended to orientate themselves with the geometry of the groove, while the neurites of the hippocampus neurons tended to grow perpendicular to shallow grooves and align themselves with deep wide grooves [191]. Similar cell response studies have investigated different surface topographical features such as gratings, posts, fibres, pores, wells and spheres [114, 150, 174, 192]. For example studies by Green et al. showed that a smooth substrate surface covered with evenly distributed $5 \mu \mathrm{m}$ diameter pores enhanced the proliferation of human fibroblast cells compared to a similar surface with pore diameters of $10 \mu \mathrm{m}$ [185]. While a study investigating the diameter and depth of a micrometre scaled well pattern evenly distributed on a smooth polydimethylsiloxane (PDMS) substrate found that by increasing the well diameter produced decreasing numbers of fibroblasts attaching to the surface [193].

4.2. Nanometre Scale Topography. Various studies have shown that nanometre scale topography is an important factor that influences protein adsorption, which in turn mediates the interaction between the cellular environment and the surface of the biomaterial [194-198]. Nanometre scale topography tends to biomimic the cell and modulating signals that are normally found in the 5 to $200 \mathrm{~nm}$ features that form part of the ECM structure [114]. The conformation of the adsorbed protein layer on the surface is critical for cell integrins to effectively interact with the underlining surface topography. These interactions are complex and result from local changes in surface properties such as chemistry, protein orientation and adsorption, wettability, and roughness [199]. Effects from surface features such as pits, pores, fibres, grooves, gratings, and spheres all increase the surface area and roughness of the substrate, which influences surface wettability, changes the local surface chemistry, and influences protein adsorption to the nanometre scale surface topography [200]. In addition, proteins with dimensions similar to those of the nanometre scale topographical features are not structurally changed by the surface, while surface features that are smaller or greater than the protein tend to influence the structural arrangement of the proteins during adsorption. This results in the proteins conforming to the nanometre scale topography of the surface [201]. Also, nanometre scale topographical features such as grooves, gratings, pits, and pores have the ability to provide sites for protein deposition, which can enhance contact guidance to cells during attachment [202-205].

The ability of cells to recognise and interact with nanometre scale surface topography has been examined using a variety of cell types and different surfaces and surface features. For example, Figure 3 presents optical and field emission scanning electron microscopy images of Cos-7, Vero and MDCK cell lines cultured on a self-organized hexagonal array of $110 \mathrm{~nm}$ diameter pores, electrochemically formed in a porous anodic aluminium oxide membrane [169]. Endothelial cells cultured on polymer demixed substrates produced a surface covered with islands of nanometre scale heights of 13, 35, and $95 \mathrm{~nm}$ [206]. The $13 \mathrm{~nm}$ high islands were found to have the most significant effect in assisting cell spreading, while the effect of the 35 and $95 \mathrm{~nm}$ high islands was less favourable. The cells found on all three surface modifications exhibited normal cell morphology and responded favourably to the nanometre scale topographical features, with proliferation rates higher than on an equivalent flat control surface [207]. Topographical features on the surface 

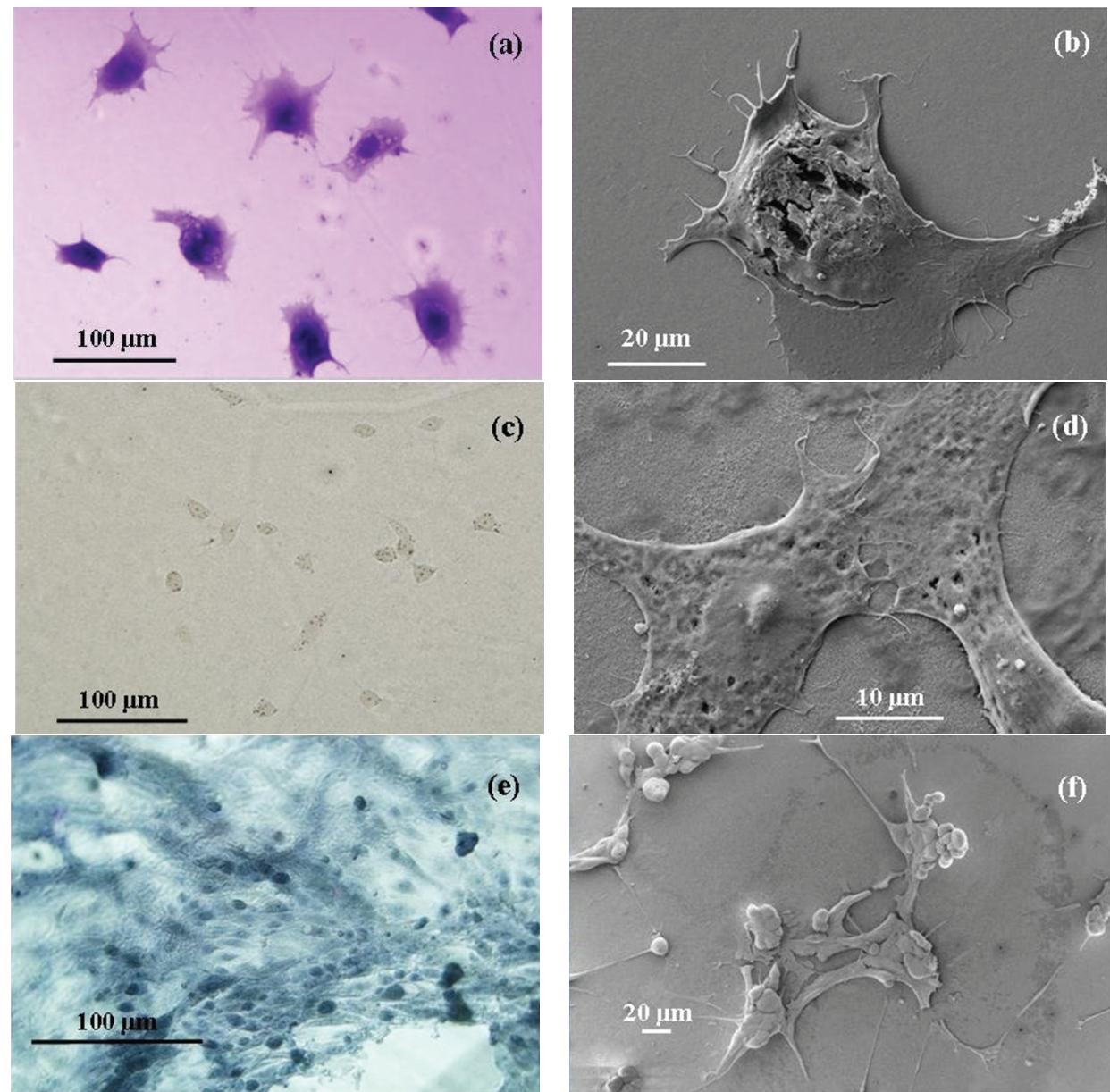

Figure 3: Optical (left) and field emission scanning electron microscopy (right) images of Cos-7 (a, b), Vero (c, d), and Madin-Darby Canine Kidney $(e, f)$ cell lines showing attachment to the electrochemically engineered Anodic Aluminium Oxide membrane. (Images taken by Murdoch Applied Nanotechnology Research Group).

of the substrate can also create physical barriers for cell-tocell contact or the surface features that could restrain cell spreading and influence cell morphology. The importance of cell-to-cell contact is clearly demonstrated when endothelial cells in contact with neighbouring cells produce significantly higher proliferation rates than single cells without neighbour contacts [208]. Epithelial cells cultured on a silicon oxide substrate covered by $70 \mathrm{~nm}$ wide nanogrooves spaced at $400 \mathrm{~nm}$ apart, produced by electron beam lithography, were found to align along the ridges of the groove. The cells appear to adhere to the surface topology using the adhesion properties of the lamellipodia and filopodia, which enables the cells to spread over the substrate [204]. Fibroblast cells have also been shown to respond to topographical surface features on a textured substrate's surface. Silica nanoparticles placed onto a substrate to increase the nanoroughness profile of the surface directly influences the behaviour of the cell's adhesion. Studies by Cousins et al. have found that the surface nanoroughness directly influences cell morphology, reduces cell adhesion, and reduces proliferation [209]. In comparison the response and behaviour of fibroblast cells changes with island topographical features. Thus fibroblast cells cultured on polymer demixed substrates with surface covered with islands of nanometre scale heights of 10 and $13 \mathrm{~nm}$ have been found to enhance cell adhesion and promote proliferation [210]. However, when 50 and $95 \mathrm{~nm}$ high islands were examined the topographical features sustained significantly less fibroblast cell adhesion than the flat control surface used. This clearly demonstrated that the size dependence of the nanometre scale topographical feature influenced the response and behaviour of the fibroblast cell [180]. On the other hand, macrophage cells cultured on a fused silica with 10 to $282 \mathrm{~nm}$ nanogrooves induced greater phagocytosis than cells grown on flat control substrates. Macrophages also tended to adhere and spread perpendicular to the direction of the grooves in the substrate [176]. Surface topographical features can also influence the behaviour of osteoblast cells, with many surface features and textures inducing greater cell adhesion and proliferation [211]. In the case of an alumina substrate surface with nanometre scale topographical features, osteoblast cell numbers were up to three times higher than a flat control alumina substrate $[20,212,213]$. In addition, the morphology of these osteoblasts can be modulated by specific nanometre scale topographic features 
such as grooves, which cause the cells to elongate and align themselves along the axis of the groove [214].

\subsection{Influence of Micrometre and Nanometre Topographical} Features on Cells. Surface topography of a substrate can present both micrometre and nanometre scale features to cells that can induce changes within the cell. Studies have shown that cells respond differently to surfaces with ordered topographical features compared to surfaces with a disordered topographical landscape with a similar roughness value. For example, a recent study by Ball et al. revealed that the response of osteoblasts to ordered micrometre scale topography was an increase in metabolic activity compared to osteoblasts on disordered micrometre scale topographical substrates [111]. The results of the study indicate the cellular responses to the substrate surfaces were influenced primarily by the topography of the surfaces, and cells on the ordered surfaces could spread or elongate successfully whilst those on the rough surfaces were constrained. In the case of multipotent mesenchymal stem cells (MSCs) a certain amount of nanometre scale disorder has been found to stimulate MSCs to produce bone minerals in vitro in the albescence of any osteogenic supplements [121, 123]. However, there is conflicting work in the literature to whether an ordered topography or a disordered topography is superior in soliciting a favourable cellular response and for inducing effective protein adsorption.

The conflicting research results in the research probably stem from trying to replicate the ECM of the particular cell type. The tissue engineered scaffold is an attempt to recreate the ECM with all of its complicated signals and stimuli that effectively solicit the appropriate cell response. The surface topographical features whether ordered or disordered are only part of creating a tissue scaffold that completely replicates the nature tissue environment of a specific cell type. And as discussed in this review each cell type responds differently to various topographical features both at the micrometre and nanometre scales. It may be the case that some cell types such as osteoblasts may respond better to an ordered topographical landscape with fixed dimensional features than a disordered or random topography. This may not be the case for all cell lines and it is only with future studies that examine various substrate topographies and materials will the ideal tissue scaffold be found that is cell specific, provides optimum protein adsorption and provides the most effective biochemical and biophysical signals to induce cellular response.

\section{Conclusion}

Topographical features on the surface of a suitable substrate can directly influence and affect cellular behaviour. The landscape of the substrate can influence cell adhesion, surface orientation, morphology, cytoskeletal development, differentiation, and proliferation. The surface topography at the nanometre scale tends to induce cell-protein responses which are similar to the signals given by its native ECM. The conformation of an adsorbed protein layer on the surface is critical for cell receptors to effectively interact with the underlining surface topography. Substrate surface topography at the micrometre scale, which has dimensions comparable to cells, has the ability to influence cell adhesion, morphology, and contact guidance. Generally, cells do not penetrate surface features such as microgrooves smaller than $2 \mu \mathrm{m}$ in width or $500 \mathrm{~nm}$ in depth [202]. However, this micrometre scale tendency is cell-dependent and can vary between cell types. On the other hand nanometre scale topography influences cell orientation on the substrate [215, 216]. During cell orientation filopodia provide details of the underlying surface nanometre scale topography. However, the recognition of the nanometre scale topography and how this information is signalled and interpreted by the cell is still an area of active investigation. Nevertheless, it is clear that any future substrate or scaffold structure for a specific tissue engineering application needs to take into account the cell type, selection of the most suitable biomaterial, and also take into account the effects of both micrometre and nanometre surface topography to solicit the most favourable cellular response for a successful clinical outcome.

\section{Conflict of Interests}

The authors report no conflict of interests in this work.

\section{Acknowledgments}

This work was partly supported by the Western Australian Nanochemistry Research Institute (WANRI). D. Fawcett would like to thank the Bill \& Melinda Gates Foundation for their research fellowship. The authors would like to thank Ms. Catherine Rinadli and Ms. Ianthe Pitout for their assistance in the cell images.

\section{References}

[1] A. Nouailhat, An Introduction to Nanoscience and Nanotechnology, John Wiley, New York, NY, USA, 2008.

[2] C. P. Poole Jr. and F. J. Owens, Introduction to Nanotechnology, John Wiley, Hoboken, NJ, USA, 2003.

[3] G. A. Ozin, A. C. Arsenault, and L. Cademartiri, Nanochemistry: A Chemical Approach to Nanomaterials, Royal Society of Chemistry, London, UK, 2005.

[4] G. Cao, Nanostructures and Nanomaterials: Synthesis, Properties and Applications, Imperial College Press, London, UK, 2004.

[5] L. Reimer, Scanning Electron Microscopy: Physics of Image Formation and Microanalysis, Springer, Heidelberg, Germany, 2nd edition, 1998.

[6] C. Singh, M. S. P. Shaffer, and A. H. Windle, "Production of controlled architectures of aligned carbon nanotubes by an injection chemical vapour deposition method," Carbon, vol. 41, no. 2, pp. 359-368, 2003.

[7] C. Bower, O. Zhou, W. Zhu, D. J. Werder, and S. Jin, "Nucleation and growth of carbon nanotubes by microwave plasma chemical vapor deposition," Applied Physics Letters, vol. 77, no. 17, pp. 2767-2769, 2000.

[8] K. Itatani, K. Iwafune, F. S. Howell, and M. Aizawa, "Preparation of various calcium-phosphate powders by ultrasonic spray 
freeze-drying technique," Materials Research Bulletin, vol. 35, no. 4, pp. 575-585, 2000.

[9] G. E. Poinern, R. K. Brundavanam, N. Mondinos, and Z. T. Jiang, "Synthesis and characterisation of nanohydroxyapatite using an ultrasound assisted method," Ultrasonics Sonochemistry, vol. 16, no. 4, pp. 469-474, 2009.

[10] E. Camponeschi, J. Walker, H. Garmestani, and R. Tannenbaum, "Surfactant effects on the particle size of iron (III) oxides formed by sol-gel synthesis," Journal of Non-Crystalline Solids, vol. 354, no. 34, pp. 4063-4069, 2008.

[11] K. M. S. Khalil and S. A. Makhlouf, "High surface area thermally stabilized porous iron oxide/silica nanocomposites via a formamide modified sol-gel process," Applied Surface Science, vol. 254, no. 13, pp. 3767-3773, 2008.

[12] W. M. Becker, L. J. Kleinsmith, and J. Hardin, The World of the Cell, Pearson, Benjamin, Cummings, 6th edition, 2006.

[13] E. K. F. Yim and K. W. Leong, "Significance of synthetic nanostructures in dictating cellular response," Nanomedicine, vol. 1, no. 1, pp. 10-21, 2005.

[14] C. Rappaport, "Small aspect of the growth of mammalian cells on glass surfaces," in The Chemistry of Bio Surfaces, M. L. Hair, Ed., pp. 449-489, Marcel Dekker, New York, NY, USA, 1972.

[15] E. A. Volger, "Interfacial chemistry in biomaterials science," in Wettability, J. C. Berg, Ed., pp. 184-250, Marcel Dekker, New York, NY, USA, 1993.

[16] F. Grinnell, "Cellular adhesiveness and extracellular substrata," International Review of Cytology, vol. 53, pp. 65-144, 1978.

[17] E. M. Christenson, K. S. Anseth, J. J. J. P. Van den Beucken et al., "Nanobiomaterial applications in orthopedics," Journal of Orthopaedic Research, vol. 25, no. 1, pp. 11-22, 2007.

[18] T. J. Webster and T. A. Smith, "Increased osteoblast function on PLGA composites containing nanophase titania," Journal of Biomedical Materials Research A, vol. 74, no. 4, pp. 677-686, 2005.

[19] C. Yao, V. Perla, J. L. McKenzie, E. B. Slamovich, and T. J. Webster, "Anodized Ti and Ti6Al4V possessing nanometer surface features enhances osteoblast adhesion," Journal of Biomedical Nanotechnology, vol. 1, no. 1, pp. 68-73, 2005.

[20] T. J. Webster, C. Ergun, R. H. Doremus, R. W. Siegel, and R. Bizios, "Enhanced functions of osteoblasts on nanophase ceramics," Biomaterials, vol. 21, no. 17, pp. 1803-1810, 2000.

[21] R. Langer and J. P. Vacanti, “Tissue engineering," Science, vol. 260, no. 5110, pp. 920-926, 1993.

[22] J. Shi, A. R. Votruba, O. C. Farokhzad, and R. Langer, "Nanotechnology in drug delivery and tissue engineering: from discovery to applications," Nano Letters, vol. 10, no. 9, pp. 32233230, 2010.

[23] A. Khademhosseini, J. P. Vacanti, and R. Langer, "Progress in tissue," Scientific American, vol. 300, no. 5, pp. 64-71, 2009.

[24] L. G. Parkinson, N. L. Giles, K. F. Adcroft, M. W. Fear, F. M. Wood, and G. E. Poinern, "The potential of nanoporous anodic aluminium oxide membranes to influence skin wound repair," Tissue Engineering A, vol. 15, no. 12, pp. 3753-3763, 2009.

[25] F. Yang, W. L. Neeley, M. J. Moore, J. M. Karp, A. Shukla, and R. Langer, "Tissue engineering: the therapeutic strategy of the twenty-first century," in Nanotechnology and Tissue Engineering: The Scaffold, C. T. Laurencin and L. S. Nair, Eds., pp. 3-24, Taylor \& Francis Group, LLC, Boca Raton, Fla, USA, 2008.

[26] M. P. Lutolf and J. A. Hubbell, "Synthetic biomaterials as instructive extracellular microenvironments for morphogenesis in tissue engineering," Nature Biotechnology, vol. 23, no. 1, pp. $47-55,2005$.
[27] C. Liu, Z. Xia, and J. T. Czernuszka, "Design and development of three dimensional scaffolds for tissue engineering," Chemical Engineering Research and Design, vol. 85, no. 7, pp. 1051-1064, 2007.

[28] R. Langer and D. A. Tirrell, "Designing materials for biology and medicine," Nature, vol. 428, no. 6982, pp. 487-492, 2004.

[29] R. G. Thakar, Q. Cheng, S. Patel et al., "Cell-shape regulation of smooth muscle cell proliferation," Biophysical Journal, vol. 96, no. 8, pp. 3423-3432, 2009.

[30] A. S. G. Curtis and P. Clark, "The effects of topographic and mechanical properties of materials on cell behavior," Critical Reviews in Biocompatibility, vol. 5, no. 4, pp. 343-362, 1990.

[31] B. Geiger, A. Bershadsky, R. Pankov, and K. M. Yamada, "Transmembrane extracellular matrix-cytoskeleton crosstalk," Nature Reviews Molecular Cell Biology, vol. 2, no. 11, pp. 793805, 2001.

[32] M. M. Stevens and J. H. George, "Exploring and engineering the cell surface interface," Science, vol. 310, no. 5751, pp. 1135-1138, 2005.

[33] M. Goldberg, R. Langer, and X. Jia, "Nanostructured materials for applications in drug delivery and tissue engineering," Journal of Biomaterials Science, Polymer Edition, vol. 18, no. 3, pp. 241-268, 2007.

[34] E. D. Hay, Cell Biology of Extracellular Matrix, Plenum Press, New York, NY, USA, 1991.

[35] J. J. Norman and T. A. Desai, "Methods for fabrication of nanoscale topography for tissue engineering scaffolds," Annals of Biomedical Engineering, vol. 34, no. 1, pp. 89-101, 2006.

[36] R. V. Shevchenko, S. L. James, and S. E. James, "A review of tissue-engineered skin bioconstructs available for skin reconstruction," Journal of the Royal Society Interface, vol. 7, no. 43, pp. 229-258, 2010.

[37] S. Oh, K. S. Brammer, Y. S. Julie-Li et al., "Stem cell fate dictated solely by altered nano-tube dimension," Proceedings of the National Academy of Sciences of the United States of America, vol. 106, no. 7, pp. 2130-2135, 2009.

[38] R. G. Harrison, "On the stereotropism of embryonic cells," Science, vol. 34, no. 870, pp. 279-281, 1911.

[39] P. Weiss, "In vitro experiments on the factors determining the course of the outgrowing nerve fibre," Journal of Experimental Zoology, vol. 68, pp. 393-448, 1934.

[40] P. Weiss, "Experiments on cell and axon orientation in vitro: the role of colloidal exudates in tissue organisation," Journal of Experimental Zoology, vol. 100, pp. 353-386, 1945.

[41] C. Allmeling, A. Jokuszies, K. Reimers, S. Kall, and P. M. Vogt, "Use of spider silk fibres as an innovative material in a biocompatible artificial nerve conduit," Journal of Cellular and Molecular Medicine, vol. 10, no. 3, pp. 770-777, 2006.

[42] J. J. Norman, J. M. Collins, S. Sharma, B. Russell, and T. A. Desai, "Microstructures in 3D biological gels affect cell proliferation," Tissue Engineeringc A, vol. 14, no. 3, pp. 379-390, 2008.

[43] R. O. Hynes, "Integrins: bidirectional, allosteric signaling machines," Cell, vol. 110, no. 6, pp. 673-687, 2002.

[44] "Classes of materials used within the body and implantation effects: handbook of test methods to enable the generation of a materials biocompatibility index," University of Liverpool, United Kingdom, 17-26, 1998.

[45] F. H. Silver, Scope and Markets for Medical Implants: Biomaterials, Medical Devices and Tissue Engineering an Integrated Approach, Chapman and Hall, London, UK, 1994, Silver F. H. Editor. 
[46] L. Yang and L. M. Zhang, "Chemical structural and chain conformational characterization of some bioactive polysaccharides isolated from natural sources," Carbohydrate Polymers, vol. 76, no. 3, pp. 349-361, 2009.

[47] V. R. Sinha and R. Kumria, "Polysaccharides in colon-specific drug delivery," International Journal of Pharmaceutics, vol. 224, no. 1-2, pp. 19-38, 2001.

[48] G. Crini, "Recent developments in polysaccharide-based materials used as adsorbents in wastewater treatment," Progress in Polymer Science, vol. 30, no. 1, pp. 38-70, 2005.

[49] A. Kanazawa and M. Suzuki, "Solid-state polycondensation of natural aldopentoses and 6-deoxyaldohexoses. Facile preparation of highly branched polysaccharide," Polymer, vol. 47, no. 1, pp. 176-183, 2006.

[50] R. Sun, J. M. Fang, A. Goodwin, J. M. Lawther, and A. J. Bolton, "Fractionation and characterization of polysaccharides from abaca fibre," Carbohydrate Polymers, vol. 37, no. 4, pp. 351-359, 1998.

[51] M. N. V. Ravi Kumar, "A review of chitin and chitosan applications," Reactive and Functional Polymers, vol. 46, no. 1, pp. 1-27, 2000.

[52] X. Wang, Y. Du, J. Luo, B. Lin, and J. F. Kennedy, "Chitosan/organic rectorite nanocomposite films: structure, characteristic and drug delivery behaviour," Carbohydrate Polymers, vol. 69, no. 1, pp. 41-49, 2007.

[53] J. M. Dang and K. W. Leong, "Natural polymers for gene delivery and tissue engineering," Advanced Drug Delivery Reviews, vol. 58, no. 4, pp. 487-499, 2006.

[54] M. L. Lorenzo-Lamosa, C. Remuñán-López, J. L. Vila-Jato, and M. J. Alonso, "Design of microencapsulated chitosan microspheres for colonic drug delivery," Journal of Controlled Release, vol. 52, no. 1-2, pp. 109-118, 1998.

[55] M. George and T. E. Abraham, "Polyionic hydrocolloids for the intestinal delivery of protein drugs: alginate and chitosan-a review," Journal of Controlled Release, vol. 114, no. 1, pp. 1-14, 2006.

[56] D. Thacharodi and K. P. Rao, "Development and in vitro evaluation of chitosan-based transdermal drug delivery systems for the controlled delivery of propranolol hydrochloride," Biomaterials, vol. 16, no. 2, pp. 145-148, 1995.

[57] M. Halbleib, T. Skurk, C. De Luca, D. Von Heimburg, and $\mathrm{H}$. Hauner, "Tissue engineering of white adipose tissue using hyaluronic acid-based scaffolds. I: in vitro differentiation of human adipocyte precursor cells on scaffolds," Biomaterials, vol. 24, no. 18, pp. 3125-3132, 2003.

[58] J. Jagur-Grodzinski, "Biomedical application of functional polymers," Reactive and Functional Polymers, vol. 39, no. 2, pp. 99138, 1999.

[59] M. G. Cascone, B. Sim, and S. Downes, "Blends of synthetic and natural polymers as drug delivery systems for growth hormone," Biomaterials, vol. 16, no. 7, pp. 569-574, 1995.

[60] K. Kafedjiiski, R. K. R. Jetti, F. Föger et al., "Synthesis and in vitro evaluation of thiolated hyaluronic acid for mucoadhesive drug delivery," International Journal of Pharmaceutics, vol. 343, no. 1-2, pp. 48-58, 2007.

[61] S. Jockenhoevel, G. Zund, S. P. Hoerstrup et al., "Fibrin geladvantages of a new scaffold in cardiovascular tissue engineering," European Journal of Cardio-Thoracic Surgery, vol. 19, no. 4, pp. 424-430, 2001.

[62] E. A. Ryan, L. F. Mockros, A. M. Stern, and L. Lorand, "Influence of a natural and a synthetic inhibitor of factor XIIIa on fibrin clot rheology," Biophysical Journal, vol. 77, no. 5, pp. 2827-2836, 1999.

[63] T. H. Chun, K. B. Hotary, F. Sabeh, A. R. Saltiel, E. D. Allen, and S. J. Weiss, "A pericellular collagenase directs the 3-dimensional development of white adipose tissue," Cell, vol. 125, no. 3, pp. 577-591, 2006.

[64] N. T. Dai, M. R. Williamson, N. Khammo, E. F. Adams, and A. G. A. Coombes, "Composite cell support membranes based on collagen and polycaprolactone for tissue engineering of skin," Biomaterials, vol. 25, no. 18, pp. 4263-4271, 2004.

[65] T. Sato, G. Chen, T. Ushida et al., "Evaluation of PLLA-collagen hybrid sponge as a scaffold for cartilage tissue engineering," Materials Science and Engineering C, vol. 24, no. 3, pp. 365-372, 2004.

[66] S. Agarwal, J. H. Wendorff, and A. Greiner, "Progress in the field of electro-spinning for tissue engineering applications," Advanced Materials, vol. 21, no. 32-33, pp. 3343-3351, 2009.

[67] Y. Dong and S. S. Feng, "Methoxy poly(ethylene glycol)poly(lactide) (MPEG-PLA) nanoparticles for controlled delivery of anticancer drugs," Biomaterials, vol. 25, no. 14, pp. 28432849, 2004.

[68] X. Zheng, B. Kan, M. Gou et al., "Preparation of MPEGPLA nanoparticle for honokiol delivery in vitro," International Journal of Pharmaceutics, vol. 386, no. 1-2, pp. 262-267, 2010.

[69] J. Chen, B. Tian, X. Yin et al., "Preparation, characterization and transfection efficiency of cationic PEGylated PLA nanoparticles as gene delivery systems," Journal of Biotechnology, vol. 130, no. 2, pp. 107-113, 2007.

[70] H. Kranz and R. Bodmeier, "Structure formation and characterization of injectable drug loaded biodegradable devices: in situ implants versus in situ microparticles," European Journal of Pharmaceutical Sciences, vol. 34, no. 2-3, pp. 164-172, 2008.

[71] J. M. Kanczler, P. J. Ginty, J. J. A. Barry et al., "The effect of mesenchymal populations and vascular endothelial growth factor delivered from biodegradable polymer scaffolds on bone formation," Biomaterials, vol. 29, no. 12, pp. 1892-1900, 2008.

[72] L. Rimondini, N. Nicoli-Aldini, M. Fini, G. Guzzardella, M. Tschon, and R. Giardino, "In vivo experimental study on bone regeneration in critical bone defects using an injectable biodegradable PLA/PGA copolymer," Oral Surgery, Oral Medicine, Oral Pathology, Oral Radiology and Endodontology, vol. 99, no. 2, pp. 148-154, 2005.

[73] C. F. L. Chu, A. Lu, M. Liszkowski, and R. Sipehia, "Enhanced growth of animal and human endothelial cells on biodegradable polymers," Biochimica et Biophysica Acta, vol. 1472, no. 3, pp. 479-485, 1999.

[74] L. Calandrelli, B. Immirzi, M. Malinconico, M. G. Volpe, A. Oliva, and F. Della Ragione, "Preparation and characterisation of composites based on biodegradable polymers for in vivo application," Polymer, vol. 41, no. 22, pp. 8027-8033, 2000.

[75] Z. Wang, S. Wang, Y. Marois, R. Guidoin, and Z. Zhang, "Evaluation of biodegradable synthetic scaffold coated on arterial prostheses implanted in rat subcutaneous tissue," Biomaterials, vol. 26, no. 35, pp. 7387-7401, 2005.

[76] A. Aubert-Pouëssel, M. C. Venier-Julienne, A. Clavreul et al., "In vitro study of GDNF release from biodegradable PLGA microspheres," Journal of Controlled Release, vol. 95, no. 3, pp. 463-475, 2004.

[77] M. Qiao, D. Chen, X. Ma, and Y. Liu, "Injectable biodegradable temperature responsive PLGA-PEG-PLGA copolymers: synthesis and effect of copolymer composition on the drug release 
from the copolymer-based hydrogels," International Journal of Pharmaceutics, vol. 294, no. 1- 2, pp. 103-112, 2005.

[78] J. J. Lee, S. G. Lee, J. C. Park, Y. I. Yang, and J. K. Kim, "Investigation on biodegradable PLGA scaffold with various pore size structure for skin tissue engineering," Current Applied Physics, vol. 7, no. 1, pp. e37-e40, 2007.

[79] H. S. Yoo and T. G. Park, "Biodegradable polymeric micelles composed of doxorubicin conjugated PLGA-PEG block copolymer," Journal of Controlled Release, vol. 70, no. 1-2, pp. 63-70, 2001.

[80] M. Todo, S. D. Park, T. Takayama, and K. Arakawa, "Fracture micromechanisms of bioabsorbable PLLA/PCL polymer blends," Engineering Fracture Mechanics, vol. 74, no. 12, pp. 1872-1883, 2007.

[81] F. Rezgui, M. Swistek, J. M. Hiver, C. G'Sell, and T. Sadoun, "Deformation and damage upon stretching of degradable polymers (PLA and PCL)," Polymer, vol. 46, no. 18, pp. 7370-7385, 2005.

[82] B. Li, J. Yu, J. Jung, and M. Ree, "Amidolysis of some biodegradable polymers," Polymer Degradation and Stability, vol. 65, no. 1, pp. 161-163, 1999.

[83] Y. Iwasaki, S. I. Sawada, K. Ishihara, G. Khang, and H. B. Lee, "Reduction of surface-induced inflammatory reaction on PLGA/MPC polymer blend," Biomaterials, vol. 23, no. 18, pp. 3897-3903, 2002.

[84] Y. Li, J. Nothnagel, and T. Kissel, "Biodegradable brush-like graft polymers from poly(D,L-lactide) or poly(D,L-lactideco-glycolide) and charge-modified, hydrophilic dextrans as backbone-synthesis, characterization and in vitro degradation properties," Polymer, vol. 38, no. 25, pp. 6197-6206, 1997.

[85] Y. C. Wang, M. C. Lin, D. M. Wang, and H. J. Hsieh, "Fabrication of a novel porous PGA-chitosan hybrid matrix for tissue engineering," Biomaterials, vol. 24, no. 6, pp. 1047-1057, 2003.

[86] C. Y. Hsieh, S. P. Tsai, D. M. Wang, Y. N. Chang, and H. J. Hsieh, "Preparation of $\gamma$-PGA/chitosan composite tissue engineering matrices," Biomaterials, vol. 26, no. 28, pp. 5617-5623, 2005.

[87] K. Rezwan, Q. Z. Chen, J. J. Blaker, and A. R. Boccaccini, "Biodegradable and bioactive porous polymer/inorganic composite scaffolds for bone tissue engineering," Biomaterials, vol. 27, no. 18, pp. 3413-3431, 2006.

[88] J. Kreuter, "Nanoparticulate systems for brain delivery of drugs," Advanced Drug Delivery Reviews, vol. 47, no. 1, pp. 65-81, 2001.

[89] M. L. Han and A. M. Lowman, "Biodegradable nanoparticles for drug delivery and targeting," Current Opinion in Solid State \& Materials Science, vol. 6, no. 4, pp. 319-327, 2002.

[90] J. J. Blaker, J. C. Knowles, and R. M. Day, "Novel fabrication techniques to produce microspheres by thermally induced phase separation for tissue engineering and drug delivery," Acta Biomaterialia, vol. 4, no. 2, pp. 264-272, 2008.

[91] R. Y. Kannan, H. J. Salacinski, K. M. Sales, P. E. Butler, and A. M. Seifalian, "The endothelialization of polyhedral oligomeric silsesquioxane nanocomposites: an in vitro study," Cell Biochemistry and Biophysics, vol. 45, no. 2, pp. 129-136, 2006.

[92] J. Raghunath, H. Zhang, M. J. Edirisinghe, A. Darbyshire, P. E. Butler, and A. M. Seifalian, "A new biodegradable nanocomposite based on polyhedral oligomeric silsesquioxane nanocages: cytocompatibility and investigation into electrohydrodynamic jet fabrication techniques for tissue-engineered scaffolds," Biotechnology and Applied Biochemistry, vol. 52, no. 1, pp. 1-8, 2009.
[93] R. Y. Kannan, H. J. Salacinski, M. Odlyha, P. E. Butler, and A. M. Seifalian, "The degradative resistance of polyhedral oligomeric silsesquioxane nanocore integrated polyurethanes: an in vitro study," Biomaterials, vol. 27, no. 9, pp. 1971-1979, 2006.

[94] H. Ghanbari, A. G. Kidane, G. Burriesci, B. Ramesh, A. Darbyshire, and A. M. Seifalian, "The anti-calcification potential of a silsesquioxane nanocomposite polymer under in vitro conditions: potential material for synthetic leaflet heart valve," Acta Biomaterialia, vol. 6, no. 11, pp. 4249-4260, 2010.

[95] H. Ghanbari, A. de Mel, and A. M. Seifalian, "Cardiovascular applications of polyhedral oligomeric silsesquioxane nanomaterials: a glimpse into prospective horizons," International Journal of Nanomedicine, vol. 6, pp. 775-786, 2011.

[96] K. Tanaka, K. Inafuku, K. Naka, and Y. Chujo, "Enhancement of entrapping ability of dendrimers by a cubic silsesquioxane core," Organic and Biomolecular Chemistry, vol. 6, no. 21, pp. 3899-3901, 2008.

[97] S. Ramakrishna, M. Ramalingam, T. S. Sampath Kumar, and W. O. Soboyejo, "Recent trends in biomaterials," in Biomaterials: A Nano Approach, pp. 22-27, CRC Press, Boca Raton, Fla, USA, 1st edition, 2010.

[98] R. S. Greco, F. B. Prinz, R. L. Smith, and editors, Nanoscale Technology in Biological Systems, CRC Press, Boca Raton, Fla, USA, 1st edition, 2005.

[99] M. G. Lines, "Nanomaterials for practical functional uses," Journal of Alloys and Compounds, vol. 449, no. 1- 2, pp. 242-245, 2008.

[100] S. K. Misra, D. Mohn, T. J. Brunner et al., "Comparison of nanoscale and microscale bioactive glass on the properties of P(3HB)/Bioglass composites," Biomaterials, vol. 29, no. 12, pp. $1750-1761,2008$

[101] S. D. Koutsostathis, G. A. Tsakotos, I. Papakostas, and G. A. Macheras, "Biological processes at bone-porous tantalum interface," Journal of Orthopaedic, vol. 6, no. 4, pp. e3-e11, 2009.

[102] J. D. Bobyn, G. J. Wilson, and D. C. MacGregor, "Effect of pore size on the peel strength of attachment of fibrous tissue to porous-surfaced implants," Journal of Biomedical Materials Research, vol. 16, no. 5, pp. 571-584, 1982.

[103] J. D. Bobyn, K. K. Toh, S. A. Hacking, M. Tanzer, and J. J. Krygier, "Tissue response to porous tantalum acetabular cups: a canine model," Journal of Arthroplasty, vol. 14, no. 3, pp. 347-354, 1999.

[104] S. A. Hacking, J. D. Bobyn, K. K. Toh, M. Tanzer, and J. J. Krygier, "Fibrous tissue in growth and attachment to porous tantalum," Journal of Biomedical Materials Research A, vol. 52, no. 4, pp. 631-638, 2000.

[105] A. Khalil, C. Aponte, R. Zhang et al., "Image analysis of softtissue in-growth and attachment into highly porous alumina ceramic foam metals," Medical Engineering and Physics, vol. 31, no. 7, pp. 775-783, 2009.

[106] M. Karlsson, A. Johansson, L. Tang, and M. Boman, "Nanoporous aluminium oxide affects neutrophil behaviour," Microscopy Research and Technique, vol. 63, no. 5, pp. 259-265, 2004.

[107] K. C. Popat, K. I. Chalvanichkul, G. L. Barnes, T. J. Latempa, C. A. Grimes, and T. A. Desai, "Osteogenic differentiation of marrow stromal cells cultured on nanoporous alumina surfaces," Journal of Biomedical Materials Research A, vol. 80, no. 4, pp. 955-964, 2007.

[108] F. M. Veronese, O. Schiavon, G. Pasut et al., "PEG-doxorubicin conjugates: influence of polymer structure on drug release, in vitro cytotoxicity, biodistribution, and antitumor activity," Bioconjugate Chemistry, vol. 16, no. 4, pp. 775-784, 2005. 
[109] H. L. Wong, A. M. Rauth, R. Bendayan et al., "A new polymerlipid hybrid nanoparticle system increases cytotoxicity of doxorubicin against multidrug-resistant human breast cancer cells," Pharmaceutical Research, vol. 23, no. 7, pp. 1574-1585, 2006.

[110] M. D. Timmer, H. Shin, R. A. Horch, C. G. Ambrose, and A. G. Mikos, "In vitro cytotoxicity of injectable and biodegradable poly(propylene fumarate)-based networks: unreacted macromers, cross-linked networks, and degradation products," Biomacromolecules, vol. 4, no. 4, pp. 1026-1033, 2003.

[111] J. M. Anderson, A. Rodriguez, and D. T. Chang, "Foreign body reaction to biomaterials," Seminars in Immunology, vol. 20, no. 2, pp. 86-100, 2008.

[112] E. Lamers, F. Walboomers, M. Domanski et al., "In vitro and in vivo evaluation of the inflammatory response to nanoscale grooved substrates," Nanomedicine, Nanotechnology, Biology and Medicine, vol. 8, pp. 308-317, 2012.

[113] B. M. Gumbiner, "Cell adhesion: the molecular basis of tissue architecture and morphogenesis," Cell, vol. 84, no. 3, pp. 345357, 1996.

[114] R. G. Flemming, C. J. Murphy, G. A. Abrams, S. L. Goodman, and P. F. Nealey, "Effects of synthetic micro- and nanostructured surfaces on cell behavior," Biomaterials, vol. 20, no. 6, pp. 573-588, 1999.

[115] S. Huang and D. E. Ingber, "The structural and mechanical complexity of cell-growth control," Nature Cell Biology, vol. 1, no. 5, pp. E131-138, 1999.

[116] E. A. O’Toole, "Extracellular matrix and keratinocyte migration," Clinical and Experimental Dermatology, vol. 26, no. 6, pp. 525-530, 2001.

[117] R. O. Hynes, "The extracellular matrix: not just pretty fibrils," Science, vol. 326, no. 5957, pp. 1216-1219, 2009.

[118] E. Lavik and R. Langer, "Tissue engineering: current state and perspectives," Applied Microbiology and Biotechnology, vol. 65, no. 1, pp. 1-8, 2004.

[119] B. C. Isenberg, P. A. DiMilla, M. Walker, S. Kim, and J. Y. Wong, "Vascular smooth muscle cell durotaxis depends on substrate stiffness gradient strength," Biophysical Journal, vol. 97, no. 5, pp. 1313-1322, 2009.

[120] J. R. Tse and A. J. Engler, "Stiffness gradients mimicking in vivo tissue variation regulate mesenchymal stem cell fate," PLoS ONE, vol. 6, no. 1, Article ID e15978, 2011.

[121] L. E. McNamara, R. J. McMurray, M. J. P. Biggs, F. Kantawong, R. O. C. Oreffo, and M. J. Dalby, "Nanotopographical control of stem cell differentiation," Journal of Tissue Engineering, Article ID 120623, pp. 1-13, 2010.

[122] K. A. Lazopoulos and D. Stamenović, "Durotaxis as an elastic stability phenomenon," Journal of Biomechanics, vol. 41, no. 6 , pp. 1289-1294, 2008.

[123] A. S. Rowlands, P. A. George, and J. J. Cooper-White, "Directing osteogenic and myogenic differentiation of MSCs: interplay of stiffness and adhesive ligand presentation," American Journal of Physiology, vol. 295, no. 4, pp. C1037-C1044, 2008.

[124] A. M. Kloxin, J. A. Benton, and K. S. Anseth, "In situ elasticity modulation with dynamic substrates to direct cell phenotype," Biomaterials, vol. 31, no. 1, pp. 1-8, 2010.

[125] E. C. Peters, M. Petro, F. Svec, and J. M. J. Fréchet, "Molded rigid polymer monoliths as separation media for capillary electrochromatography. 1. Fine control of porous properties and surface chemistry," Analytical Chemistry, vol. 70, no. 11, pp. 2288-2295, 1998.
[126] T. P. Kunzler, T. Drobek, M. Schuler, and N. D. Spencer, “Systematic study of osteoblast and fibroblast response to roughness by means of surface-morphology gradients," Biomaterials, vol. 28, no. 13 , pp. 2175-2182, 2007.

[127] D. C. Miller, A. Thapa, K. M. Haberstroh, and T. J. Webster, "Endothelial and vascular smooth muscle cell function on poly(lactic-co-glycolic acid) with nano-structured surface features," Biomaterials, vol. 25, no. 1, pp. 53-61, 2004.

[128] M. Ibn-Elhaj and M. Schadt, "Optical polymer thin films with isotropic and anisotropic nano-corrugated surface topologies," Nature, vol. 410, no. 6830, pp. 796-799, 2001.

[129] S. Kim and P. A. Coulombe, "Intermediate filament scaffolds fulfill mechanical, organizational, and signaling functions in the cytoplasm," Genes and Development, vol. 21, no. 13, pp. 15811597, 2007.

[130] A. S. Andersson, F. Bäckhed, A. Von Euler, A. Richter-Dahlfors, D. Sutherland, and B. Kasemo, "Nanoscale features influence epithelial cell morphology and cytokine production," Biomaterials, vol. 24, no. 20, pp. 3427-3436, 2003.

[131] B. Knox, P. Ladiges, and B. Evans, Biology, McGraw-Hill, Sydney, Australia, 1994.

[132] C. J. Bettinger, R. Langer, and J. T. Borenstein, "Engineering substrate topography at the Micro- and nanoscale to control cell function," Angewandte Chemie, vol. 48, no. 30, pp. 5406-5415, 2009.

[133] N. J. Sniadecki, R. A. Desai, S. A. Ruiz, and C. S. Chen, "Nanotechnology for cell-substrate interactions," Annals of Biomedical Engineering, vol. 34, no. 1, pp. 59-74, 2006.

[134] L. Wang and R. L. Carrier, "Biomimetic topography: bioinspired cell culture substrates and scaffolds," in Advances in Biomimetics, A. George, Ed., chapter 21, pp. 454-472, INTECH, Vienna, Austria, 2011.

[135] E. Martínez, E. Engel, J. A. Planell, and J. Samitier, "Effects of artificial micro- and nano-structured surfaces on cell behaviour," Annals of Anatomy, vol. 191, no. 1, pp. 126-135, 2009.

[136] T. W. Gilbert, T. L. Sellaro, and S. F. Badylak, "Decellularization of tissues and organs," Biomaterials, vol. 27, no. 19, pp. 36753683, 2006.

[137] S. F. Badylak, D. Taylor, and K. Uygun, "Whole-organ tissue engineering: decellularization and recellularization of threedimensional matrix scaffolds," Annual Review of Biomedical Engineering, vol. 13, pp. 27-53, 2011.

[138] D. W. Courtman, C. A. Pereira, V. Kashef, D. McComb, J. M. Lee, and G. J. Wilson, "Development of a pericardial acellular matrix biomaterial: biochemical and mechanical effects of cell extraction," Journal of Biomedical Materials Research, vol. 28, no. 6, pp. 655-666, 1994.

[139] C. E. Schmidt and J. M. Baier, "Acellular vascular tissues: natural biomaterials for tissue repair and tissue engineering," Biomaterials, vol. 21, no. 22, pp. 2215-2231, 2000.

[140] S. L. M. Dahl, J. Koh, V. Prabhakar, and L. E. Niklason, "Decellularized native and engineered arterial scaffolds for transplantation," Cell Transplantation, vol. 12, no. 6, pp. 659666, 2003.

[141] B. S. Conklin, E. R. Richter, K. L. Kreutziger, D. S. Zhong, and C. Chen, "Development and evaluation of a novel decellularized vascular xenograft," Medical Engineering and Physics, vol. 24, no. 3, pp. 173-183, 2002.

[142] M. T. Kasimir, E. Rieder, G. Seebacher et al., "Comparison of different decellularization procedures of porcine heart valves," International Journal of Artificial Organs, vol. 26, no. 5, pp. 421427, 2003. 
[143] R. W. Grauss, M. G. Hazekamp, F. Oppenhuizen, C. J. Van Munsteren, A. C. Gittenberger-De Groot, and M. C. DeRuiter, "Histological evaluation of decellularised porcine aortic valves: matrix changes due to different decellularisation methods," European Journal of Cardio-Thoracic Surgery, vol. 27, no. 4, pp. 566-571, 2005.

[144] F. Chen, J. J. Yoo, and A. Atala, "Acellular collagen matrix as a possible "off the shelf" biomaterial for urethral repair," Urology, vol. 54, no. 3, pp. 407-410, 1999.

[145] D. O. Freytes, S. F. Badylak, T. J. Webster, L. A. Geddes, and A. E. Rundell, "Biaxial strength of multilaminated extracellular matrix scaffolds," Biomaterials, vol. 25, no. 12, pp. 2353-2361, 2004.

[146] S. F. Badylak, G. C. Lantz, A. Coffey, and L. A. Geddes, "Small intestinal submucosa as a large diameter vascular graft in the dog," Journal of Surgical Research, vol. 47, no. 1, pp. 74-80, 1989.

[147] M. S. Sacks and D. C. Gloeckner, "Quantification of the fiber architecture and biaxial mechanical behaviour of porcine intestinal submucosa," Journal of Biomedical Materials Research, vol. 46, pp. 1-10, 1999.

[148] P. Lin, W. C. W. Chan, S. F. Badylak, and S. N. Bhatia, "Assessing porcine liver-derived biomatrix for hepatic tissue engineering," Tissue Engineering, vol. 10, no. 7-8, pp. 1046-1053, 2004.

[149] B. E. Uygun, A. Soto-Gutierrez, H. Yagi et al., "Organ reengineering through development of a transplantable recellularized liver graft using decellularized liver matrix," Nature Medicine, vol. 16, no. 7, pp. 814-820, 2010.

[150] R. N. Chen, H. O. Ho, Y. T. Tsai, and M. T. Sheu, "Process development of an acellular dermal matrix (ADM) for biomedical applications," Biomaterials, vol. 25, no. 13, pp. 2679-2686, 2004.

[151] T. H. Petersen, E. A. Calle, L. Zhao et al., "Tissue-engineered lungs for in vivo implantation," Science, vol. 329, no. 5991, pp. 538-541, 2010.

[152] H. C. Ott, T. S. Matthiesen, S. K. Goh et al., "Perfusiondecellularized matrix: using nature's platform to engineer a bioartificial heart," Nature Medicine, vol. 14, no. 2, pp. 213-221, 2008.

[153] E. Stoffels, W. W. Stoffels, and G. M. W. Kroesen, "Plasma chemistry and surface processes of negative ions," Plasma Sources Science and Technology, vol. 10, no. 2, pp. 311-317, 2001.

[154] D. M. Brunette, G. S. Kenner, and T. R. Gould, "Grooved titanium surfaces orient growth and migration of cells from human gingival explants," Journal of Dental Research, vol. 62, no. 10, pp. 1045-1048, 1983.

[155] C. L. Randall, E. Gultepe, and D. H. Gracias, "Self-folding devices and materials for biomedical applications," Trends in Biotechnology, vol. 30, no. 3, pp. 138-146, 2011.

[156] A. J. Birnbaum and A. Pique, "Laser induced extra-planar propulsion for three dimensional microfabrication," Applied Physics Letters, vol. 98, pp. 134101-134106, 2011.

[157] R. Nielson, B. Kaehr, and J. B. Shear, "Microreplication and design of biological architectures using dynamic-mask multiphoton lithography," Small, vol. 5, no. 1, pp. 120-125, 2009.

[158] D. Liang, B. S. Hsiao, and B. Chu, "Functional electrospun nanofibrous scaffolds for biomedical applications," Advanced Drug Delivery Reviews, vol. 59, no. 14, pp. 1392-1412, 2007.

[159] W. J. Li, C. T. Laurencin, E. J. Caterson, R. S. Tuan, and F. K. Ko, "Electrospun nanofibrous structure: a novel scaffold for tissue engineering," Journal of Biomedical Materials Research, vol. 60, no. 4, pp. 613-621, 2002.
[160] M. Schindler, I. Ahmed, J. Kamal et al., "A synthetic nanofibrillar matrix promotes in vivo-like organization and morphogenesis for cells in culture," Biomaterials, vol. 26, no. 28, pp. 5624-5631, 2005.

[161] Y. Hu, D. W. Grainger, S. R. Winn, and J. O. Hollinger, "Fabrication of $\operatorname{poly}(\alpha$-hydroxy acid) foam scaffolds using multiple solvent systems," Journal of Biomedical Materials Research, vol. 59, no. 3, pp. 563-572, 2002.

[162] K. W. Chun, K. C. Cho, S. H. Kim, J. H. Jeong, and T. G. Park, "Controlled release of plasmid DNA from biodegradable scaffolds fabricated using a thermally-induced phase-separation method," Journal of Biomaterials Science, Polymer Edition, vol. 15, no. 11, pp. 1341-1353, 2004.

[163] K. Whang, C. H. Thomas, K. E. Healy, and G. Nuber, "A novel method to fabricate bioabsorbable scaffolds," Polymer, vol. 36, no. 4, pp. 837-842, 1995.

[164] X. Liu, J. Y. Lim, H. J. Donahue, R. Dhurjati, A. M. Mastro, and E. A. Vogler, "Influence of substratum surface chemistry/energy and topography on the human fetal osteoblastic cell line hFOB 1.19: phenotypic and genotypic responses observed in vitro," Biomaterials, vol. 28, no. 31, pp. 4535-4550, 2007.

[165] B. G. Keselowsky, D. M. Collard, and A. J. García, "Surface chemistry modulates fibronectin conformation and directs integrin binding and specificity to control cell adhesion," Journal of Biomedical Materials Research A, vol. 66, no. 2, pp. 247259, 2003.

[166] P. X. Ma, "Biomimetic materials for tissue engineering," Advanced Drug Delivery Reviews, vol. 60, no. 2, pp. 184-198, 2008.

[167] G. Cook, P. L. Timms, and C. Göltner-Spickermann, "Exact replication of biological structures by chemical vapor deposition of silica," Angewandte Chemie, vol. 42, no. 5, pp. 557-559, 2003.

[168] J. Park, S. Bauer, K. Von Der Mark, and P. Schmuki, "Nanosize and vitality: $\mathrm{TiO}_{2}$ nanotube diameter directs cell fate," Nano Letters, vol. 7, no. 6, pp. 1686-1691, 2007.

[169] G. E. J. Poinern, N. Ali, and D. Fawcett, "Progress in nanoengineered anodic aluminium oxide membrane development," Materials, vol. 4, pp. 487-526, 2011.

[170] C. A. Pfluger, D. D. Burkey, L. Wang, B. Sun, K. S. Ziemer, and R. L. Carrier, "Biocompatibility of plasma enhanced chemical vapor deposited poly(2-hydroxyethyl methacrylate) films for biomimetic replication of the intestinal basement membrane," Biomacromolecules, vol. 11, no. 6, pp. 1579-1584, 2010.

[171] M. D. Rosenberg, "Long-range interactions between cell and substratum," Proceedings of the National Academy of Sciences of the United States of America, vol. 48, pp. 1342-1349, 1962.

[172] M. D. Rosenberg, "Cell guidance by alterations in monomolecular films," Science, vol. 139, no. 3553, pp. 411-412, 1963.

[173] P. Clark, P. Connolly, and A. S. G. Curtis, "Topographical control of cell behaviour. I. Simple step cues," Development, vol. 99, no. 3, pp. 439-448, 1987.

[174] P. Clark, P. Connolly, A. S. G. Curtis, J. A. T. Dow, and C. D. W. Wilkinson, "Topographical control of cell behaviour: II. multiple grooved substrata," Development, vol. 108, no. 4, pp. 635-644, 1990.

[175] L. Chou, J. D. Firth, V. J. Uitto, and D. M. Brunette, "Substratum surface topography alters cell shape and regulates fibronectin mRNA level, mRNA stability, secretion and assembly in human fibroblasts," Journal of Cell Science, vol. 108, no. 4, pp. 1563-1573, 1995. 
[176] B. Wójciak-Stothard, A. Curtis, W. Monaghan, K. Macdonald, and C. Wilkinson, "Guidance and activation of murine macrophages by nanometric scale topography," Experimental Cell Research, vol. 223, no. 2, pp. 426-435, 1996.

[177] F. J. O’Brien, B. A. Harley, I. V. Yannas, and L. J. Gibson, "The effect of pore size on cell adhesion in collagen-GAG scaffolds," Biomaterials, vol. 26, no. 4, pp. 433-441, 2005.

[178] C. S. Ranucci and P. V. Moghe, "Substrate microtopography can enhance cell adhesive and migratory responsiveness to matrix ligand density," Journal of Biomedical Materials Research, vol. 54, no. 2, pp. 149-161, 2001.

[179] J. R. McMillan, M. Akiyama, M. Tanaka et al., "Small-diameter porous poly ( $\varepsilon$-caprolactone) films enhance adhesion and growth of human cultured epidermal keratinocyte and dermal fibroblast cells," Tissue Engineering, vol. 13, no. 4, pp. 789-798, 2007.

[180] M. J. Dalby, M. O. Riehle, H. Johnstone, S. Affrossman, and A. S. G. Curtis, "Investigating the limits of filopodial sensing: a brief report using SEM to image the interaction between $10 \mathrm{~nm}$ high nano-topography and fibroblast filopodia," Cell Biology International, vol. 28, no. 3, pp. 229-236, 2004.

[181] G. A. Dunn and J. P. Heath, "A new hypothesis of contact guidance in tissue cells," Experimental Cell Research, vol. 101, no. 1, pp. 1-14, 1976.

[182] P. T. Ohara and R. C. Buck, "Contact guidance in vitro. A light, transmission, and scanning electron microscopic study," Experimental Cell Research, vol. 121, no. 2, pp. 235-249, 1979.

[183] G. A. Dunn, "Contact guidance of cultured tissue cells: a survey of potentially relevant properties of the substratum," in Cell Behavior, R. Bellairs, A. Curtis, and G. Dunn, Eds., Cambridge University Press, Cambridge, UK, 1982.

[184] G. A. Dunn, "How do cells respond to ultrafine surface contours?” Bioessays, vol. 13, no. 10, pp. 541-543, 1991.

[185] A. M. Green, J. A. Jansen, J. P. C. M. Van der Waerden, and A. F. Von Recum, "Fibroblast response to microtextured silicone surfaces: texture orientation into or out of the surface," Journal of Biomedical Materials Research, vol. 28, no. 5, pp. 647-653, 1994.

[186] B. Chehroudi and D. M. Burnette, "Effects of surface topography on cell behaviour," in Encylopedic Handbook of Biomaterials and Bioengineering. Part A: Materials, D. J. Trantolo, D. E. Altobelli, M. J. Yaszemski, G. D. Gresser, and E. R. Schwartz, Eds., Marcel Dekker, New York, NY, USA, 1995.

[187] A. Curtis and C. Wilkinson, "Topographical control of cell migration," in Motion Analysis of Living Cells, D. R. Insoll and D. Wessels, Eds., Wiley-Liss, 1998.

[188] A. Wood, "Contact guidance on microfabricated substrata: the response of teleost fin mesenchyme cells to repeating topographical patterns," Journal of Cell Science, vol. 90, pp. 667681, 1988.

[189] S. Britland, C. Perridge, M. Denyer, H. Morgan, A. Curtis, and C. Wilkinson, "Morphogenetic guidance cues can interact synergistically and hierarchically in steering nerve cell growth," Experimental Biology Online, vol. 1, pp. 1-15, 1997.

[190] J. L. Charest, M. T. Eliason, A. J. García, and W. P. King, "Combined microscale mechanical topography and chemical patterns on polymer cell culture substrates," Biomaterials, vol. 27, no. 11, pp. 2487-2494, 2006.

[191] A. M. Rajnicek, S. Britland, and C. D. McCaig, "Contact guidance of CNS neurites on grooved quartz: influence of groove dimensions, neuronal age and cell type," Journal of Cell Science, vol. 110, no. 23, pp. 2905-2913, 1997.
[192] J. Meyle, K. Gultig, and W. Nisch, "Variation in contact guidance by human cells on a microstructured surface," Journal of Biomedical Materials Research, vol. 29, no. 1, pp. 81-88, 1995.

[193] S. Kidambi, N. Udpa, S. A. Schroeder, R. Findlan, I. Lee, and C. Chan, "Cell adhesion on polyelectrolyte multilayer coated polydimethylsiloxane surfaces with varying topographies," Tissue Engineering, vol. 13, no. 8, pp. 2105-2117, 2007.

[194] A. Curtis and C. Wilkinson, "Nantotechniques and approaches in biotechnology," Trends in Biotechnology, vol. 19, no. 3, pp. 97101, 2001.

[195] A. S. G. Curtis, N. Gadegaard, M. J. Dalby, M. O. Riehle, C. D. W. Wilkinson, and G. Aitchison, "Cells react to nanoscale order and symmetry in their surroundings," IEEE Transactions on Nanobioscience, vol. 3, no. 1, pp. 61-65, 2004.

[196] K. Rechendorff, M. B. Hovgaard, M. Foss, V. P. Zhdanov, and F. Besenbacher, "Enhancement of protein adsorption induced by surface roughness," Langmuir, vol. 22, no. 26, pp. 10885-10888, 2006.

[197] M. S. Lord, M. Foss, and F. Besenbacher, "Influence of nanoscale surface topography on protein adsorption and cellular response," Nano Today, vol. 5, no. 1, pp. 66-78, 2010.

[198] M. J. Dalby, S. J. Yarwood, M. O. Riehle, H. J. H. Johnstone, S. Affrossman, and A. S. G. Curtis, "Increasing fibroblast response to materials using nanotopography: morphological and genetic measurements of cell response to 13-nm-high polymer demixed islands," Experimental Cell Research, vol. 276, no. 1, pp. 1-9, 2002.

[199] C. J. Wilson, R. E. Clegg, D. I. Leavesley, and M. J. Pearcy, "Mediation of biomaterial-cell interactions by adsorbed proteins: a review," Tissue Engineering, vol. 11, no. 1-2, pp. 1-18, 2005.

[200] M. B. Hovgaard, K. Rechendorff, J. Chevallier, M. Foss, and F. Besenbacher, "Fibronectin adsorption on tantalum: the influence of nanoroughness," Journal of Physical Chemistry B, vol. 112 , no. 28, pp. 8241-8249, 2008.

[201] E. Macarena Blanco, M. A. Horton, and P. Mesquida, "Simultaneous investigation of the influence of topography and charge on protein adsorption using artificial nanopatterns," Langmuir, vol. 24, no. 6, pp. 2284-2287, 2008.

[202] E. T. Den Braber, J. E. De Ruijter, H. T. J. Smits, L. A. Ginsel, A. F. Von Recum, and J. A. Jansen, "Quantitative analysis of cell proliferation and orientation on substrata with uniform parallel surface micro-grooves," Biomaterials, vol. 17, no. 11, pp. 10931099, 1996.

[203] E. T. Den Braber, J. E. De Ruijter, L. A. Ginsel, A. F. Von Recum, and J. A. Jansen, "Orientation of ECM protein deposition, fibroblast cytoskeleton, and attachment complex components on silicone microgrooved surfaces," Journal of Biomedical Materials Research, vol. 40, no. 2, pp. 291-300, 1998.

[204] A. I. Teixeira, G. A. Abrams, P. J. Bertics, C. J. Murphy, and P. F. Nealey, "Epithelial contact guidance on well-defined microand nanostructured substrates," Journal of Cell Science, vol. 116, no. 10, pp. 1881-1892, 2003.

[205] E. K. F. Yim, R. M. Reano, S. W. Pang, A. F. Yee, C. S. Chen, and K. W. Leong, "Nanopattern-induced changes in morphology and motility of smooth muscle cells," Biomaterials, vol. 26, no. 26, pp. 5405-5413, 2005.

[206] M. J. Dalby, M. O. Riehle, H. Johnstone, S. Affrossman, and A. S. G. Curtis, "In vitro reaction of endothelial cells to polymer demixed nanotopography," Biomaterials, vol. 23, no. 14, pp. 2945-2954, 2002.

[207] S. Buttiglieri, D. Pasqui, M. Migliori et al., "Endothelization and adherence of leucocytes to nanostructured surfaces," Biomaterials, vol. 24, no. 16, pp. 2731-2738, 2003. 
[208] C. M. Nelson and C. S. Chen, "Cell-cell signaling by direct contact increases cell proliferation via a PI3K-dependent signal," FEBS Letters, vol. 514, no. 2-3, pp. 238-242, 2002.

[209] B. G. Cousins, P. J. Doherty, R. L. Williams, J. Fink, and M. J. Garvey, "The effect of silica nanoparticulate coatings on cellular response," Journal of Materials Science, vol. 15, no. 4, pp. 355359, 2004.

[210] M. J. Dalby, M. O. Riehle, H. J. H. Johnstone, S. Affrossman, and A. S. G. Curtis, "Polymer-demixed nanotopography: control of fibroblast spreading and proliferation," Tissue Engineering, vol. 8, no. 6, pp. 1099-1108, 2002.

[211] J. Lovmand, J. Justesen, M. Foss et al., "The use of combinatorial topographical libraries for the screening of enhanced osteogenic expression and mineralization," Biomaterials, vol. 30, no. 11, pp. 2015-2022, 2009.

[212] T. J. Webster, R. W. Siegel, and R. Bizios, "Osteoblast adhesion on nanophase ceramics," Biomaterials, vol. 20, no. 13, pp. 12211227, 1999.

[213] T. J. Webster, R. W. Siegel, and R. Bizios, "Design and evaluation of nanophase alumina for orthopaedic/dental applications," Nanostructured Materials, vol. 12, no. 5, pp. 983-986, 1999.

[214] J. Y. Yang, Y. C. Ting, J. Y. Lai, H. L. Liu, H. W. Fang, and W. B. Tsai, "Quantitative analysis of osteoblast-like cells (MG63) morphology on nanogrooved substrata with various groove and ridge dimensions," Journal of Biomedical Materials Research A, vol. 90, no. 3, pp. 629-640, 2009.

[215] P. Clark, P. Connolly, A. S. G. Curtis, J. A. T. Dow, and C. D. W. Wilkinson, "Cell guidance by ultrafine topography in vitro," Journal of Cell Science, vol. 99, no. 1, pp. 73-77, 1991.

[216] P. Clark, P. Connolly, and G. R. Moores, "Cell guidance by micropatterned adhesiveness in vitro," Journal of Cell Science, vol. 103, no. 1, pp. 287-292, 1992. 

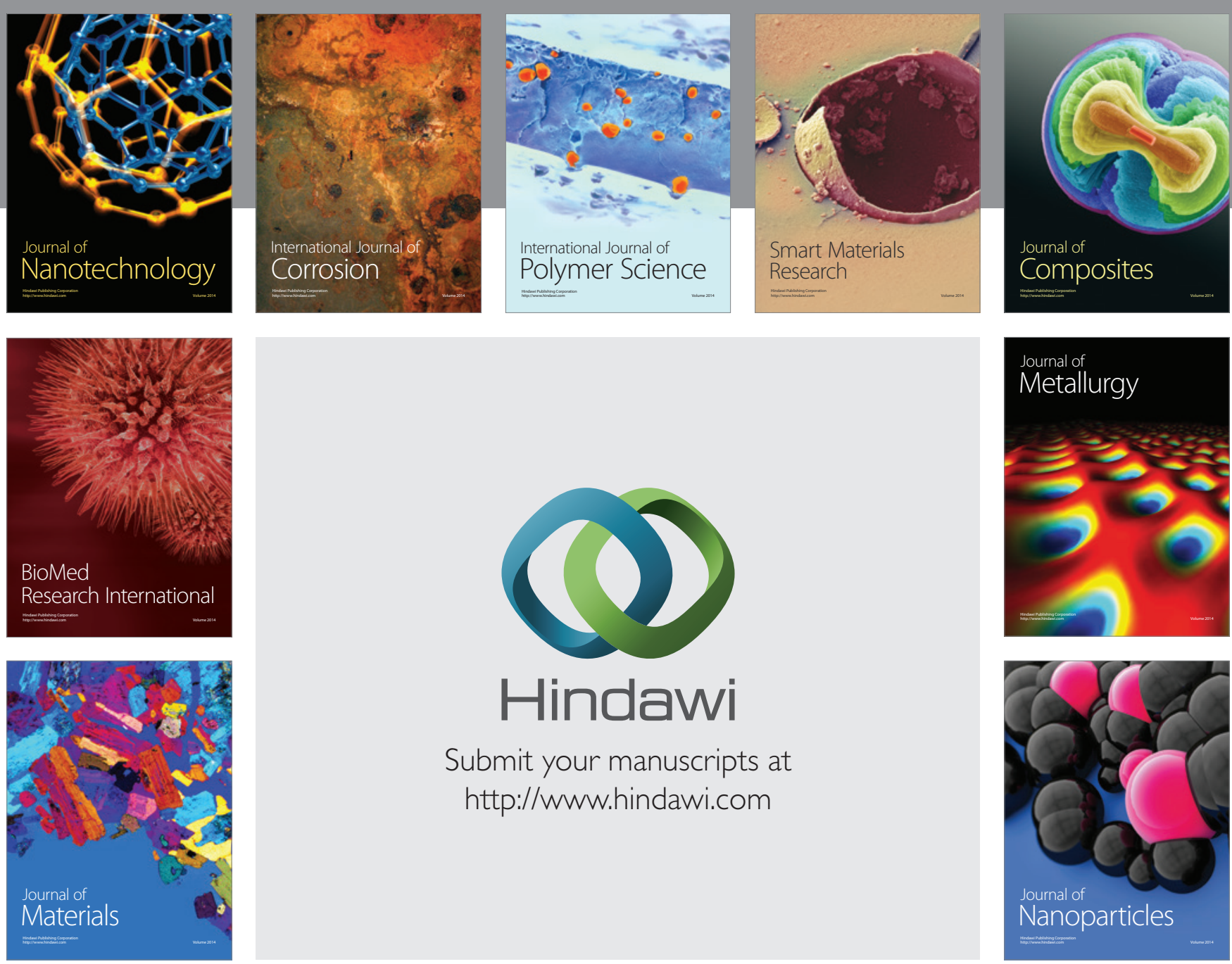

Submit your manuscripts at http://www.hindawi.com
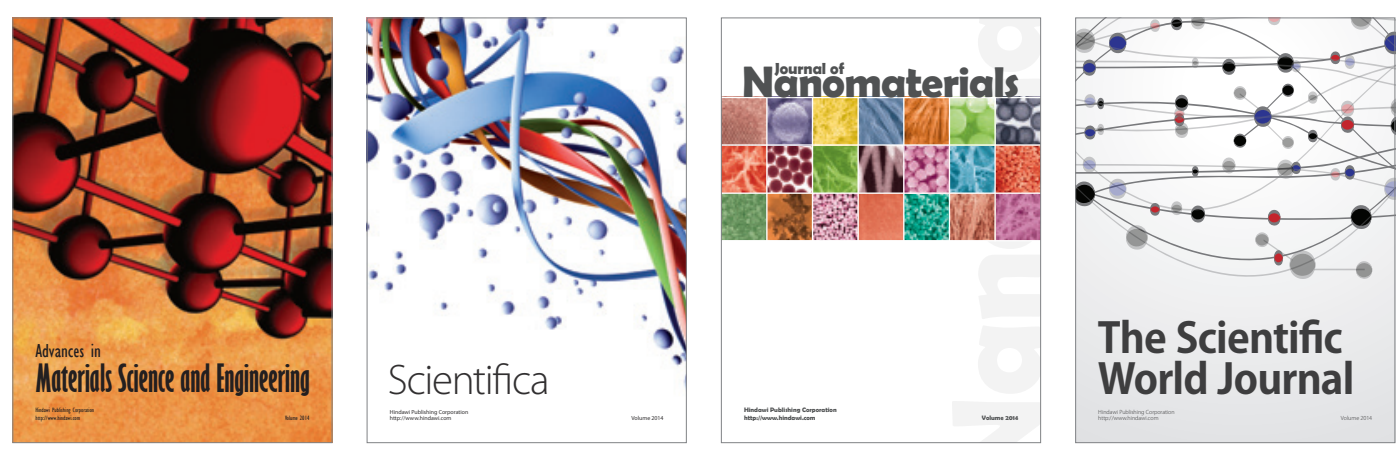

\section{The Scientific World Journal}
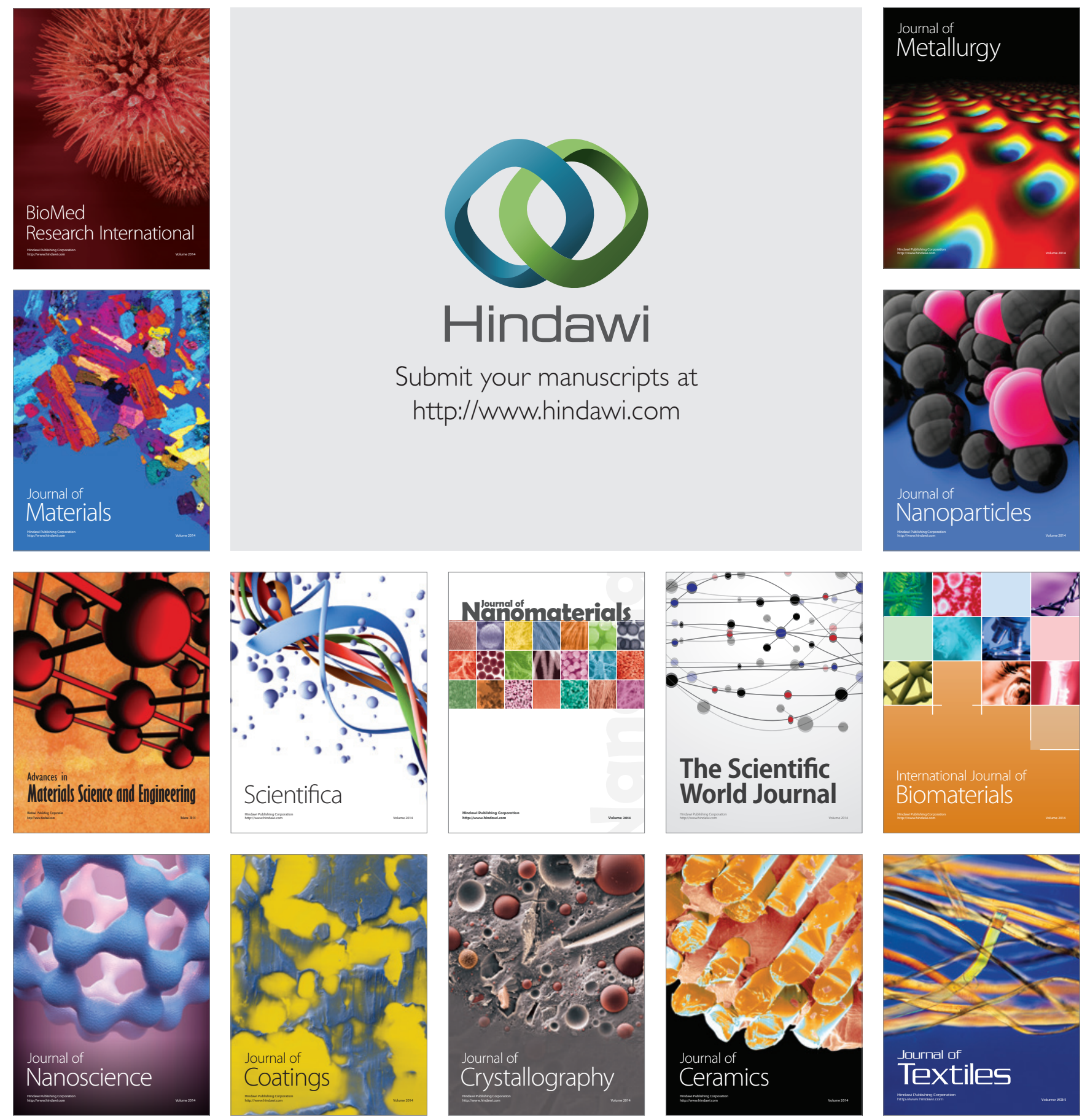